\title{
Endoplasmic reticulum-to-Golgi transitions upon herpes virus
}

\section{infection [version 1; peer review: 2 approved with}

\section{reservations]}

\author{
Peter Wild(D1,2, Andres Kaech³, Elisabeth M. Schraner1,2, Ladina Walser², \\ Mathias Ackermann ${ }^{1}$
}

${ }^{1}$ Institute of Virology, Zürich, Switzerland

2Institute of Veterinary Anatomy, Zürich, Switzerland

${ }^{3}$ Center for Microscopy and Image Analysis, Zürich, Switzerland

V1 First published: 05 Oct 2017, 6:1804
https://doi.org/10.12688/f1000 research.12252.1

Latest published: 28 Feb 2018, 6:1804

https://doi.org/10.12688/f1000research.12252.2

\section{Abstract}

Background: Herpesvirus capsids are assembled in the nucleus before they are translocated to the perinuclear space by budding, acquiring tegument and envelope, or releasing to the cytoplasm in a "naked" state via impaired nuclear envelope. One model proposes that envelopment, "de-envelopment" and "re-envelopment" are essential steps for production of infectious virus. Glycoproteins gB/gH were reported to be essential for de-envelopment, by fusion of the "primary" envelope with the outer nuclear membrane. Yet, a high proportion of enveloped virions generated from genomes with deleted $\mathrm{gB} / \mathrm{gH}$ were found in the cytoplasm and extracellular space, suggesting the existence of an alternative exit route.

Methods: We investigated the relatedness between the nuclear envelope and membranes of the endoplasmic reticulum and Golgi complex, in cells infected with either herpes simplex virus 1 (HSV-1) or a Us3 deletion mutant thereof, or with bovine herpesvirus 1 (BoHV-1) by transmission and scanning electron microscopy, employing freezing technique protocols that lead to improved spatial and temporal resolution.

Results: Scanning electron microscopy showed the Golgi complex as a compact entity in a juxtanuclear position covered by a membrane on the cis face. Transmission electron microscopy revealed that Golgi membranes merge with membranes of the endoplasmic reticulum forming an entity with the perinuclear space. All compartments contained enveloped virions. After treatment with brefeldin A, HSV-1 virions aggregated in the perinuclear space and endoplasmic reticulum, while infectious progeny virus was still produced. Conclusions: The data strongly suggest that virions are intraluminally transported from the perinuclear space via Golgi complexendoplasmic reticulum transitions into Golgi cisternae for packaging

\section{Open Peer Review}

\begin{tabular}{|c|c|c|c|c|}
\hline & 1 & 2 & 3 & 4 \\
\hline \\
\hline (revision) & & $\checkmark$ & view & view \\
\hline 28 Feb 2018 & & 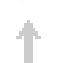 & & \\
\hline version 1 & $?$ & $?$ & & \\
\hline 05 Oct 2017 & view & view & & \\
\hline
\end{tabular}

1. Charles Grose, University of Iowa, Iowa City, USA

2. Gareth Griffiths, University of Oslo, Oslo, Norway

3. Alexandre A. Mironov (D), FIRC Institute of Molecular Oncology Foundation (IFOM), Milan, Italy

4. José A Martínez-Menárguez (iD), University of Murcia, Murcia, Spain

Any reports and responses or comments on the article can be found at the end of the article. 
into transport vacuoles. Furthermore, virions derived by budding at nuclear membranes are infective as has been shown for HSV-1 Us3 deletion mutants, which almost entirely accumulate in the perinuclear space. Therefore, de-envelopment followed by re-envelopment is not essential for production of infective progeny virus.

\section{Keywords}

herpes virus, envelopment, egress pathway, endoplasmic reticulum,

Golgi complex, intraluminal transport, brefeldin A

Corresponding author: Peter Wild (pewild@access.uzh.ch)

Author roles: Wild P: Conceptualization, Data Curation, Funding Acquisition, Investigation, Methodology, Project Administration, Supervision, Writing - Original Draft Preparation; Kaech A: Data Curation, Formal Analysis, Methodology, Visualization; Schraner EM: Formal Analysis, Investigation, Methodology; Walser L: Formal Analysis, Investigation; Ackermann M: Resources, Validation, Writing Review \& Editing

Competing interests: No competing interests were disclosed.

Grant information: This study was supported by the Foundation for Scientific Research at the University of Zürich, Switzerland. The funders had no role in study design, data collection and analysis, decision to publish, or preparation of the manuscript.

Copyright: $\odot 2017$ Wild P et al. This is an open access article distributed under the terms of the Creative Commons Attribution License, which permits unrestricted use, distribution, and reproduction in any medium, provided the original work is properly cited. Data associated with the article are available under the terms of the Creative Commons Zero "No rights reserved" data waiver (CC0 1.0 Public domain dedication).

How to cite this article: Wild $P$, Kaech A, Schraner EM et al. Endoplasmic reticulum-to-Golgi transitions upon herpes virus infection [version 1; peer review: 2 approved with reservations] F1000Research 2017, 6:1804 https://doi.org/10.12688/f1000research.12252.1

First published: 05 Oct 2017, 6:1804 https://doi.org/10.12688/f1000research.12252.1 


\section{Introduction}

The Golgi complex plays a crucial role in the secretory pathway. Cargo is transported from the endoplasmic reticulum (ER) to the Golgi complex via vesicles that derive from ER exit sites (Bonifacino \& Glick, 2004). Tubules are involved in anterograde as well as in retrograde transport (Lippincott-Schwartz et al., 1990; Lippincott-Schwartz et al., 1989). The sole paradigm of vesicular transport between ER and Golgi may evolve to account for the results of new technologies (Lippincott-Schwartz, 2011). Indeed, cargo may also be transported through an ER-Golgi intermediate compartment (ERGIC) (Hauri \& Schweizer, 1992; Klumperman, 2000; Saraste et al., 2009). Whether the ERGIC is a stable structure, is under debate (Ben-Tekaya et al., 2005). There are also transitional elements connecting Golgi membranes to ER membranes (Pavelka \& Roth, 2015; Polishchuk \& Mironov, 2004; Vivero-Salmeron et al., 2008) possibly enabling direct transportation of cargo from ER cisternae into Golgi cisternae. Once in the Golgi cisternae, cargo is packaged into secretory granules for exocytotic release (Palade, 1975). Packaging of cargo is accompanied by loss of Golgi membranes. To maintain Golgi structure and function, multiple recycling processes take place (Orci et al., 1981). Although the structure and function of the Golgi complex has been investigated for decades, many uncertainties remain e.g. Golgi maturation and functionality of the trans Golgi network (TGN) (Emr et al., 2009).

The Golgi complex plays also a crucial role in herpes virus morphogenesis and intracellular transport (Roizman et al., 2014). Herpes viruses comprise the capsid, tegument and envelope, with embedded glycoproteins. Capsids are assembled in nuclei of host cells and transported to the Golgi complex concomitantly acquiring the envelope and tegument. Three diverse pathways have been proposed. In pathways 1 and 3 (summarized in Figure 11), capsids directed to the nuclear periphery are released into the perinuclear space (PNS) by budding at the inner nuclear membrane (INM) acquiring an electron dense envelope and tegument. In pathway 1, these perinuclear virions are intraluminally transported (Gilbert et al., 1994; Granzow et al., 1997; Radsak et al., 1996; Schwartz \& Roizman, 1969; Stannard et al., 1996; Sutter et al., 2012; Whealy et al., 1991; Wild et al., 2002) into ER cisternae, whose membranes are connected to the outer nuclear membrane (ONM). These virions were suggested to be transported via ER-Golgi transitions into Golgi cisternae (Leuzinger et al., 2005; Wild et al., 2015; Wild et al., 2002). Importantly, intraluminal transportation requires mechanisms for preventing the viral envelope from fusion with the membrane the virions are transported along.

In pathway 2, capsids are released from the nuclear periphery into the cytoplasmic matrix via impaired nuclear pores (Leuzinger et al., 2005; Wild et al., 2005; Wild et al., 2009) or disrupted nuclear membranes (Borchers \& Oezel, 1993; Klupp et al., 2011). Notably, pore impairment is the initial step in breakdown of the nuclear envelope (Terasaki et al., 2001) that takes place when HSV-1 infection proceeds (Maric et al., 2014). The capsids in the cytoplasmic matrix are transported to any site of the Golgi complex (Wild et al., 2002) and are enveloped either by wrapping (see below) or by budding into Golgi cisternae and/or vacuoles, which may enlarge to engulf multiple virions (Homman-Loudiyi et al., 2003; Leuzinger et al., 2005;
Stannard et al., 1996; Sutter et al., 2012; Wild et al., 2015; Wild et al., 2002). Capsids bud, though less frequently, also at the ONM and RER membranes (Leuzinger et al., 2005; Wild et al., 2005), and are intraluminally transported as in pathway 1 .

According to pathway 3, virions in the PNS are de-enveloped by fusion of the viral envelope with the ONM or with adjacent ER membranes releasing capsid and tegument into the cytoplasmic matrix. These capsids then are re-enveloped by budding at membranes of the TGN (Mettenleiter et al., 2013) and endosomes (Albecka et al., 2016; Hollinshead et al., 2012) acquiring again an envelope and tegument. Concomitantly, a small concentric transport vacuole is formed enclosing the enveloped virion. This process is referred to as wrapping (Roizman et al., 2014).

Although the phenotypes of the capsid transport across the ONM exhibit all characteristics of budding (Bonifacino \& Glick, 2004; Harrison, 2015; Jahn et al., 2003; Kanaseki et al., 1997; Lee, 2010; Mayer, 2002) the de-envelopment theory is still favored. Fusion of the viral envelope with the ONM requires the glycoproteins $\mathrm{gB}$ and $\mathrm{gH}$ (Farnsworth et al., 2007). Nonetheless, various stages of capsid transportation across the ONM and ER membranes in the absence of the glycoproteins $\mathrm{gB} / \mathrm{gH}$ have been shown. Furthermore, a substantial proportion of virions lacking $\mathrm{gB} / \mathrm{gH}$ were reported to be in the cytoplasm and extracellular space. These two facts strongly suggest another pathway of virus particles out of the PNS. The lack of profound evidence for capsid transport across the ONM via fusion, and the growing evidence of Golgi to ER transitions, prompted us to investigate the ER and Golgi compartments by cryo-field emission scanning electron microscopy (Cryo-ESEM) and transmission electron microscopy (TEM), employing protocols for improved spatial and temporal resolution (Ellinger et al., 2010; Mueller, 1992). We show that the Golgi complex is a tightly packed organelle, that ER to Golgi transitions are formed, and that virions aggregate within the ER after exposure cells to brefeldin A (BFA), which disintegrates the Golgi complex within minutes (Hess et al., 2000), suggesting an intraluminal transportation route. Moreover, we observe that intraluminal virions are densely coated with a proteinaceous layer that arises during budding. Therefore, we propose that the significance of the dense coat is protecting the viral envelope from fusion with the membranes along which virions are transported, in a similar manner as clathrin protects coated vesicles from fusion.

\section{Materials and methods}

Cells and viruses

Vero cells and MDBK cells (European Collection of Cell Cultures) were grown in Dulbecco's modified minimal essential medium (DMEM; Gibco, Bethesda, MD, USA) supplemented with penicillin $(100 \mathrm{U} / \mathrm{ml})$, streptomycin $(100 \mu \mathrm{g} / \mathrm{ml})$ and $10 \%$ fetal bovine serum (FBS; Gibco). The Us3 deletion mutant R7041( $\Delta$ Us3) and the repair mutant R2641 (Longnecker \& Roizman, 1987; Purves et al., 1987) were kindly provided by Bernard Roizman (The Marjorie B. Kovler Viral Oncology Laboratories, University of Chicago, Illinois, USA). Wild-type herpes simplex virus 1 (wt HSV-1) strain F (Ejercito et al., J. Gen. Virol. 2:357-364, 1968), R7041(AUs3) and R2641 were propagated in Vero cells, and bovine herpes virus 1 (BoHV-1: Metzler et al., Arch. Virol. 87: 
205-217, 1986) in MDBK cells. Virus yields were determined by plaque titration.

\section{Cryo-fixation for transmission electron microscopy}

$50 \mu \mathrm{m}$ thick sapphire disks (Bruegger, Minusio, Switzerland) measuring $3 \mathrm{~mm}$ in diameter were coated with $8-10 \mathrm{~nm}$ carbon, obtained by evaporation under high vacuum conditions to enhance cell growth and to facilitate detachment of cells from the sapphire disks after embedding. Vero and MDBK cells were grown for 2 days on sapphire disks placed in 6 well plates. Cells were inoculated with $\mathrm{R} 7041(\Delta \mathrm{Us} 3)$, the repair mutant $\mathrm{R} 2641$, wt HSV- 1 or BoHV- 1 at a MOI of 5, incubated at $37^{\circ} \mathrm{C}$, and fixed at 8 to 20 hpi by adding $0.25 \%$ glutaraldehyde to the medium prior to freezing in a high-pressure freezing unit (HPM010; Science Services, Munich, Germany) and processed as described in detail (Wild, 2008). In brief, the frozen water was substituted with acetone in a freeze-substitution unit (FS 7500; Boeckeler Instruments, Tucson, AZ, USA) at $-88^{\circ} \mathrm{C}$ with acetone and subsequently fixed with $0.25 \%$ glutaraldehyde and $0.5 \%$ osmium tetroxide raising the temperature gradually to $+2{ }^{\circ} \mathrm{C}$ to achieve good contrast of membranes (Wild et al., 2001), and embedded in epon at $4^{\circ} \mathrm{C}$ followed by polymerization at $60^{\circ} \mathrm{C}$ for 2.5 days. After removal of sapphire disks by immersion in liquid nitrogen, serial sections of 60 to $90 \mathrm{~nm}$ thickness were analyzed in a transmission electron microscope (CM12; FEI, Eindhoven, The Netherlands) equipped with a CCD camera (Ultrascan 1000; Gatan, Pleasanton, CA, USA) at an acceleration voltage of $100 \mathrm{kV}$.

\section{Cell exposure to brefeldin A}

Cells grown on sapphire disks were inoculated with wt HSV-1 at a MOI of 5 and incubated at $37^{\circ} \mathrm{C}$. Stock solution (5 mg BFA solved in $0.5 \mathrm{ml}$ methanol) was diluted with medium 1:10. One $\mu \mathrm{l} / \mathrm{ml}$ medium $(1 \mu \mathrm{g} / \mathrm{ml})$ of this solution was added to cell cultures at 5, 8, 12 and 16 hpi. Cells were high-pressure frozen at indicated times, and prepared for TEM. To quantify virus phenotypes and their location, 10 images of cellular profiles were taken at random from ultrathin sections of monolayers exposed to BFA from $5,8,12$ or 16 hpi to 20 hpi of 5 independent experiments. Capsids budding at the INM, ONM, ER and Golgi membranes, capsids undergoing wrapping, as wells as virions in the PNS, ER, Golgi cisternae and vacuoles were counted. The means expressed per cellular profile were compared applying a Student's t-test using GraphPad Prism 3 software.

For determination of infectious progeny virus produced after BFA exposure, cells were grown in $10 \mathrm{ml}$ Falcon flasks, inoculated with wt HSV-1 at a MOI of 5, and exposed to BFA from 5, 8, 12 or $16 \mathrm{~h}$ to 20 hpi. Cells were harvested at 5, 8, 12, 16 and 20 hpi for determination of infectious progeny virus by plaque titration. Since the Golgi complex reacts immediately to BFA by disintegration, infectious viruses produced after BFA exposure were considered to have derived by budding at membranes other than those of the Golgi complex.

\section{Cryo-Field Emission Scanning Electron Microscopy (Cryo- FESEM)}

Vero cells were grown in $25 \mathrm{~cm}^{2}$ cell culture flasks for 2 days prior to inoculation with wt HSV-1, R7041( $\Delta \mathrm{Us} 3)$ or R2641 at MOI of 5. Cells were harvested at 9 to 12 hpi by trypsinization followed by centrifugation at $150 \mathrm{x}$ g for $8 \mathrm{~min}$. Pellet were re-suspended in $1 \mathrm{ml}$ fresh medium, collected in Eppendorf tubes and fixed by adding $0.25 \%$ glutaraldehyde to the medium. The suspension was kept in the tubes at $4^{\circ} \mathrm{C}$ until cells were sedimented. After removal of the supernatant, cells were frozen in a high-pressure freezing machine EM HPM100 (Leica Microsystems, Vienna, Austria) as described in detail previously (Wild et al., 2012; Wild et al., 2009). Cells were fractured at $-120^{\circ} \mathrm{C}$ in a freeze-fracturing device BAF 060 (Leica Microsystems) in a vacuum of $10^{-7}$ mbar. The fractured surfaces were partially freeze-dried ("etched") at $-105^{\circ} \mathrm{C}$ for $2 \mathrm{~min}$, and coated with $2.5 \mathrm{~nm}$ platinum/carbon by electron beam evaporation at an angle of $45^{\circ}$. Some specimens were coated additionally with $4 \mathrm{~nm}$ of carbon to reduce electron beam damage during imaging at high magnifications. Specimens were imaged in an Auriga 40 Cross Beam system (Zeiss, Oberkochen, Germany) equipped with a cryo-stage (Leica Microsystems) at $-115^{\circ} \mathrm{C}$ and an acceleration voltage of $5 \mathrm{kV}$ using the inlens secondary electron detector.

\section{Confocal microscopy}

Cells were grown for 2 days on $0.17 \mathrm{~mm}$ thick cover slips of $12 \mathrm{~mm}$ in diameter (Assistent, Sondheim, Germany) and inoculated with R7041( $\Delta \mathrm{Us} 3)$, wt HSV-1 or R2641 at a MOI of 5 and incubated at $37^{\circ} \mathrm{C}$. After fixation with $2 \%$ formaldehyde for $25 \mathrm{~min}$ at room temperature, cells were briefly washed with PBS and stored in PBS at $4{ }^{\circ} \mathrm{C}$ until further processing. Then, cells were permeabilized with $0.1 \%$ Triton-X-100 at room temperature for 7 min and blocked with $3 \%$ bovine serum albumin in PBS containing $0.05 \%$ Tween 20 (PBST). To ascertain infectivity, cells were labeled with antibodies against ICP4 (Life Technologies, Carlsbad, CA; USA), and Alexa 594 (Molecular Probes, Eugene, OR, USA) as secondary antibodies. To identify the Golgi complex, cells were incubated with recombinant monoclonal antibodies against the cis-Golgi protein GM130, abcam EP892Y (Abcam, Cambridge, UK) at a dilution of 1:1000 for $2 \mathrm{~h}$ at room temperature followed by incubation with Alexa 488 (Molecular Probes) as secondary antibodies, diluted 1:500, for $1 \mathrm{~h}$ at room temperature. After staining nuclei with 4',6-Diamidino-2phenylindol (DAPI; Roche, Mannheim, Germany), cells were embedded in glycergel mounting media (Dako North America, Carpinteria, CA, USA) and $25 \mathrm{mg} / \mathrm{ml} \mathrm{1,4-diazabicyclo} \mathrm{[2.2.2]}$ octane (DABCO; Fluka, Buchs, Switzerland). Specimens were analyzed using a confocal laser scanning microscope (SP2; Leica, Wetzlar, Germany). Images were deconvolved employing the deconvolution algorithm of the program suite Huygens Essential (SVI, Hilversum, The Netherlands).

\section{Results}

The Golgi complex is a tightly packed entity situated close to the nucleus

To localize the Golgi complex, we first imaged the Golgi complex by confocal microscopy after labeling the cis-face with antibodies against the Golgi protein GM 130 in Vero cells. The Golgi complex was always found close to the nucleus in HSV-1, R7041( $\Delta$ Us3), or mock infected cell (Figure 1). Next, high resolution cryo-electron microscopy of freeze fractured cells demonstrated the bell-shaped form of the Golgi complex, and its localization close to the nucleus (Figure 2). This image also shows that the Golgi complex is a complex tightly packed entity with a diameter 
of approximately $6 \mu \mathrm{m}$. The Golgi complex is separated from the cytoplasmic matrix by an intact membrane covering the whole visible surface of the cis-face. The large dimension makes clear that the detected ultrastructural details depend on a large scale on how and where the Golgi complex is hit in a given section plane for studying by TEM. Both freeze-fracture planes and thin sections of central regions show that the membrane of the outermost cisterna covers the cis-side (Figure 3).

\section{ER-to-Golgi transitions}

The Golgi complex undergoes dramatic changes during HSV-1 infection finally resulting in fragmentation and dispersion (Campadelli et al., 1993). However, the Golgi complex is not, or only minimal, involved in envelopment of R7041( $\Delta$ Us3) capsids (Wild et al., 2015). To identify ER-to-Golgi transitions, we thus imaged the Golgi complex in serial sections through wt HSV-1 or R7041( $\Delta$ Us3) infected cells by transmission electron microscopy after rapidly freezing and freeze-substitution applying a protocol especially suitable to visualize membranes (Wild et al., 2001). A series of images show that ER membranes continue into Golgi membranes. The ER runs from the perinuclear region into the
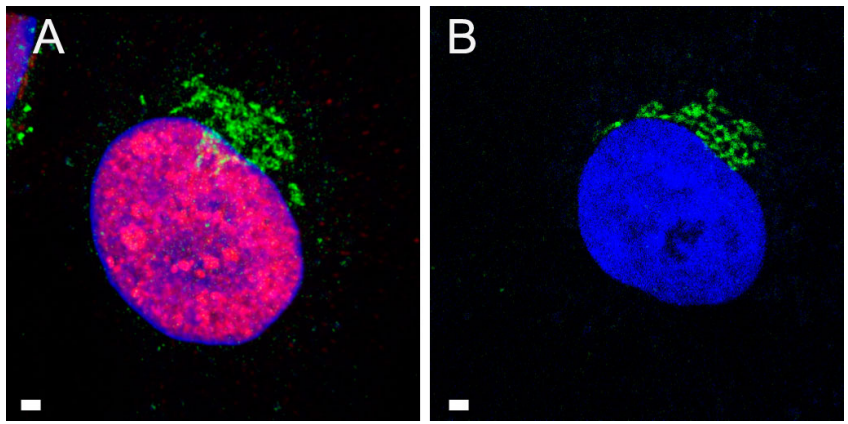

Figure 1. Confocal microscopy of Vero cells, immunolabeled with antibodies against the Golgi protein GM130 (green) and ICP4 (red) at $12 \mathrm{hpi}$ with HSV-1 (A) and after mock infection (B), showing the Golgi complex always in a juxtanuclear position. Bars: $1 \mu \mathrm{m}$.

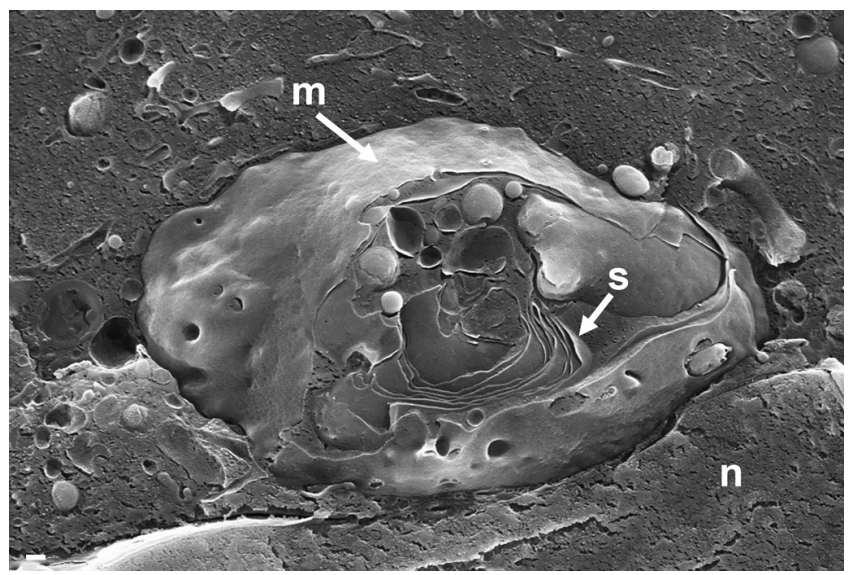

Figure 2. Cryo-FESEM of a Golgi complex in close vicinity to the nucleus ( $\mathrm{n}$ ) in a Vero cell, at $\mathbf{1 0}$ hpi with wt HSV-1. The entire visible surface is covered by an intact membrane $(\mathrm{m})$ except at the part it is broken away giving view to Golgi stacks (s). Bars: $200 \mathrm{~nm}$. membranes of the outermost Golgi stack (Figure 4A). The very same membranes continue again into ER membranes so that this Golgi cisterna is interconnected between ER lamellae. The membranes of the adjacent stack also turn into ER membranes. ER membranes also pass somewhere into central regions of Golgi fields where they are devoid of ribosomes (Figure 4BC). ER membranes may even connect two Golgi fields (Figure 4D). The ER forms, as its name implies, a network (Figure 4C) that connects to the PNS (Figure 5A).
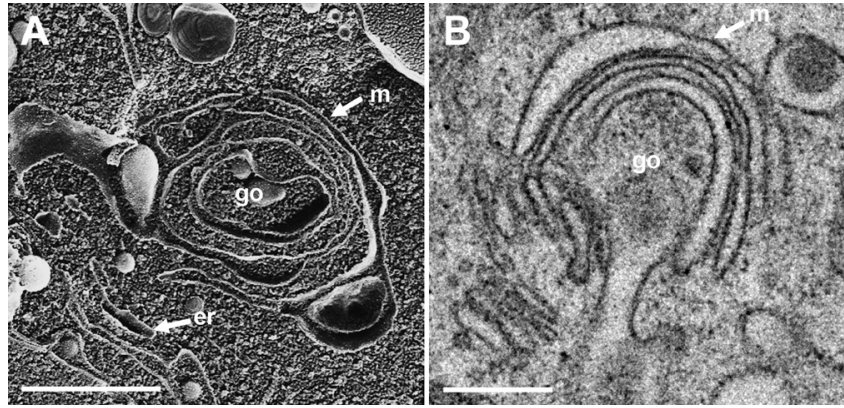

Figure 3. The Golgi complex, as revealed in freeze-fracture planes (A) and in thin sections (B), is entirely covered at the cis-face by the membrane $(\mathrm{m})$ of the outermost cisterna. Bars: $100 \mathrm{~nm}$.
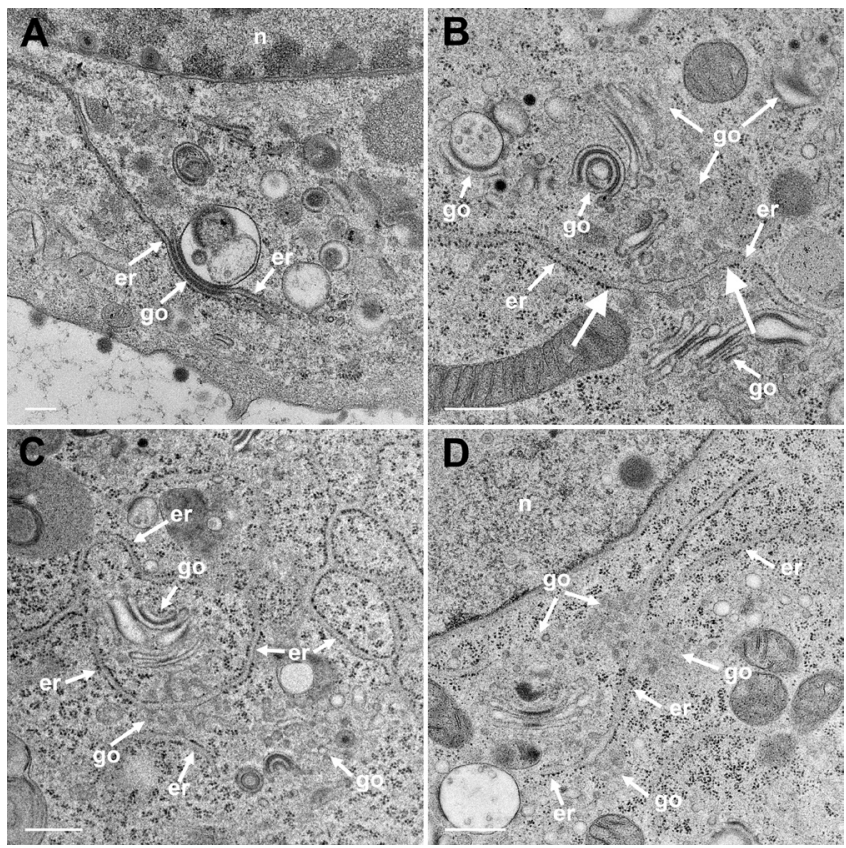

Figure 4. TEM of R7041( $\Delta$ Us3) infected Vero cells at $12 \mathrm{hpi}$. (A) The ER (er) runs from the nuclear (n) periphery towards a Golgi field (go), continuing into the membrane of the outermost stack and further into the cytoplasmic matrix. The membranes of the second stack continue also into ER membranes. (B) An ER cisterna runs through multiple small Golgi fields, whereby the ER membranes turn into Golgi membranes (thick arrows). (C) ER membranes forming a network continue into Golgi membranes. (D) ER membranes run through two Golgi fields, turning each time into Golgi membranes. Bars: $500 \mathrm{~nm}$ 


\section{Virions are within ER cisternae}

Virions within the ER have been repeatedly shown, the first report dating back to the late 1960ties (Schwartz \& Roizman, 1969). Virions were in the PNS or anywhere in ER cisternae after HSV-1 infection (Figure 5BC) as well as in Golgi cisternae of which membranes transit into ER membranes (Figure 5B). Virions accumulate in the PNS-ER compartment late in infection (Leuzinger et al., 2005; Wild et al., 2015), in the absence of Us3 (Reynolds et al., 2002; Wisner et al., 2009) or $\mathrm{gB} / \mathrm{gH}$ (Farnsworth et al., 2007) or after disintegration of the Golgi complex by BFA (Chatterjee \& Sarkar, 1992; Cheung et al., 1991; Jensen \& Norrild, 2002; Whealy et al., 1991). To investigate the effect of BFA on virus release out of the PNS we exposed cells to BFA at 5, 8, 12 and 16 hpi with wt HSV-1, and harvested cells at 20 hpi for quantitative electron microscopic analysis and determination of infectious progeny virus. Electron microscopy revealed dilation of the PNS and ER containing many virions and amorphous

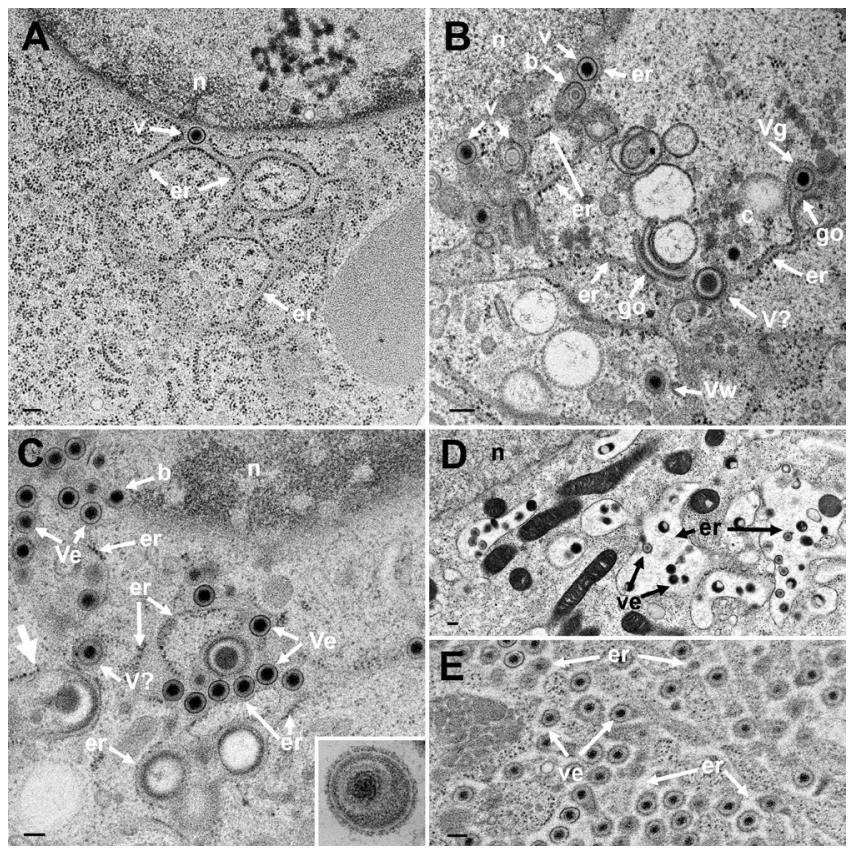

Figure 5. TEM of Vero cells at 9 hpi with R7041( $\Delta$ Us3) (A), at $16 \mathrm{hpi}(\mathbf{B})$ and at $20 \mathrm{hpi}(\mathbf{C})$ with wt HSV-1, and at 15 or $17 \mathrm{hpi}$ with wt HSV-1 and BFA exposure (D and E). (A) The ER (er) runs from the nucleus $(n)$ towards the cell periphery forming an entity with the PNS that contains a virion (v). (B) The ER contains virions. One capsid is in the stage of budding (b) into the ER. The ER continues into Golgi (go) membranes at two sites. One Golgi cisterna contains a virion $(\mathrm{Vg})$, one virion has been derived by wrapping $(\mathrm{Vw})$. Close to Golgi stacks, there is probably a virion (V?) of abnormal size. (C) One capsid buds (b) at the nuclear (n) periphery. The ER is dilated and filled with virions (Ve) and dense material: An ER membrane turns into a Golgi membrane (thick arrow). (D) After exposure to BFA from 8 to 15 hpi with wt HSV-1, the ER was dilated and contained some virions. (E) The ER was almost filled with virions after exposure to BFA from 8 to $17 \mathrm{hpi}$ with wt HSV-1. Note that virions in the PNS and ER are covered by a dense coat hiding spikes whereas spikes are clearly apparent on virions in the extracellular space (C inset). Bars: $200 \mathrm{~nm}$. material at 15 hpi (Figure 5D). At $17 \mathrm{hpi}$, the ER was congested with virions (Figure 5E). Quantitative analysis of phenotype distribution revealed that virions accumulate in the PNS-ER compartment after BFA administration in a time dependent manner. The number of intraluminal virions was 4 times higher when BFA was added at 8 hpi but 12 times higher than it was added at 16 hpi compared to that in untreated cells (Figure 6). The number of virus particles interacting with the ONM and ER membranes in BFA exposed cells was about twice as high as in controls whereas the number of capsids in the cytoplasmic matrix did not differ significantly. We thus conclude i) that the interactions at the ONM and ER membranes are budding capsids contributing to accumulation of virions in the PNS and ER, ii) that more capsids bud at the ONM and ER membranes because no Golgi membranes are available after Golgi disintegration induced by BFA, iii) that inhibition of virion release out of the PNS-ER compartment is due to a blockage of the intraluminal transportation pathway after Golgi disintegration, and iv) that the Golgi complex delivered components to budding sites prior to its disintegration by BFA.

\section{Virions in the PNS-ER compartment are infective}

Us3 is not essential (Poon et al., 2006; Reynolds et al., 2002; Ryckman \& Roller, 2004; Wisner et al., 2009). Us3 deletion mutants accumulating in the PNS are infective (Wild et al., 2015). Hence, it is reasonable to assume that wt HSV-1 virions in the PNS-ER compartment are also infective. To prove this idea, we determined infectious progeny virus by plaque titration at the time point of BFA administration and at 20 hpi. The Golgi complex completely disintegrates within less than 5 minutes after exposure of cells to BFA (Hess et al., 2000). Despite of Golgi disintegration infectious progeny virus was produced in a time

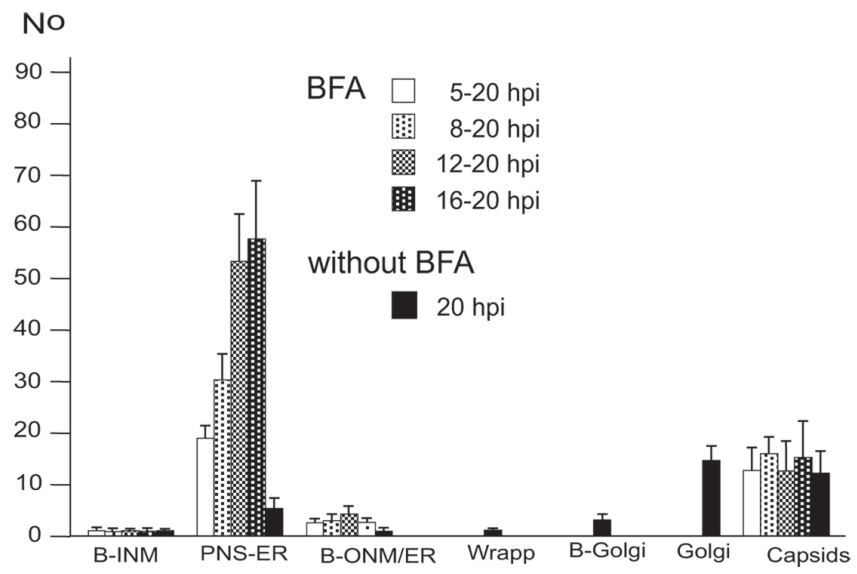

Figure 6. Means and standard deviations of the phenotype of HSV-1 infected Vero cells. BFA was added to monolayers at 5, 8, 12 or $16 \mathrm{hpi}$ (MOI of 5) and incubated until $20 \mathrm{hpi}$. For control, inoculated cells were incubated for $20 \mathrm{~h}$ without addition of BFA. Cells were rapidly frozen at $20 \mathrm{hpi}$ and processed for electron microscopy. The phenotypes of envelopment were counted in 10 cellular profiles of 5 independent experiments: Capsids budding at the INM (B-INM), at the ONM and ER membranes (B-ONM/ER) and at the Golgi complex (B-Golgi); virions in the PNS-ER compartment (PNS-ER); virions derived by wrapping (Wrapp); virions in Golgi cisternae or large vacuoles (Golgi); capsids in the cytoplasmic matrix (capsids). 
depended manner. The later BFA was added the more infectious viruses were produced by 20 hpi (Figure 7). Since virions accumulated exceptionalness in the PNS-ER compartment in BFA exposed cells we conclude that virions derived by budding at nuclear membranes are infective.

\section{PNS, ER and Golgi complex form an entity}

The nuclear envelope is part of the ER. The outer nuclear membrane (ONM) is stubbed with ribosomes. The ONM continues into ER cisternae, which, in turn, merge with Golgi cisternae. Golgi cisternae were also found to connect to the PNS via short ER-Golgi intermediates in R7041( $\Delta \mathrm{Us} 3)$ infected Vero cells (Figure 8ABC) and BoHV-1 infected MDBK cells (Figure 8D). ER-Golgi intermediates contained virus like particles (Figure 8B). The continuum between PNS and Golgi cisternae is considered likely to serve as a direct, short and efficient pathway to transport virions form the site of budding to Golgi cisternae for packaging.

\section{Virions are within Golgi cisternae and/or vacuoles}

Capsids are postulated to be enveloped at the trans Golgi network (Mettenleiter et al., 2006) by a process designated wrapping. However, capsids can bud at any location of the Golgi complex (Figure 9B) and vacuoles as have been shown for HSV-1 (Leuzinger et al., 2005; Stannard et al., 1996), BoHV-1 (Wild et al., 2002) and pseudorabies virus (Klupp et al., 2008), and even at microsomes (Albecka et al., 2016; Hollinshead et al., 2012). The result of wrapping is a small concentric vacuole (Figure 9D) containing a single virion as shown elsewhere in detail (Leuzinger et al., 2005; Wild et al., 2005). Golgi cisternae and vacuoles can contain one to numerous virions in a given section plane (Figure 9A). The cavities at the trans face of the

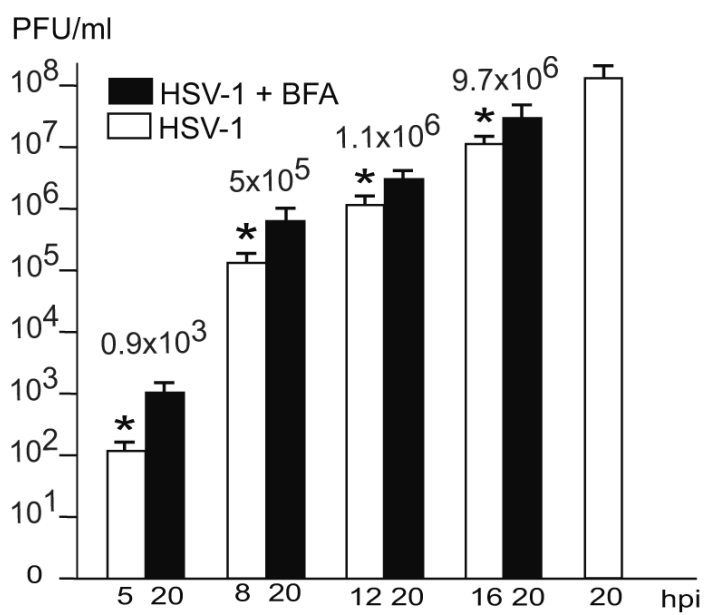

Figure 7. Virus yields at the time of BFA administration or controls (white) and at $\mathbf{2 0}$ hpi (black). The difference between virus yields (indicated with numbers) at the time of BFA addition and harvesting at $20 \mathrm{hpi}$ is considered to be due to virus production after Golgi disintegration. These infectious virions correspond to the virions accumulating in the PNS-ER compartment. $n=4, p<0.01$.

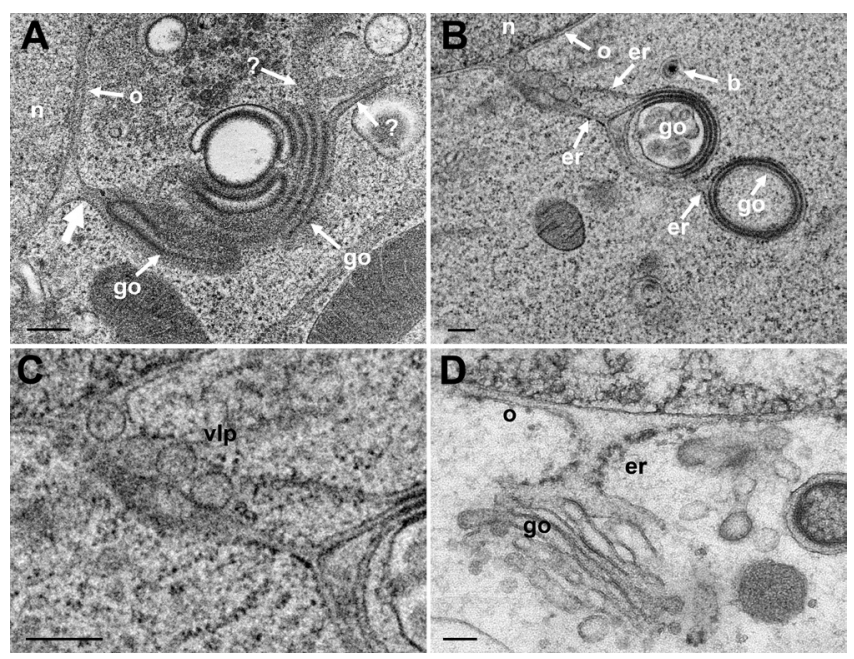

Figure 8. TEM of Vero cells at $12 \mathrm{hpi}$ with R7041( $\Delta \mathrm{Us} 3$ ) and of BoHV-1 infected MDBK cells, showing Golgi fields close to the nucleus (n). (A) Golgi (go) membranes continue (thick arrow) into the ONM (O) as well as towards the cytoplasm indicated by (?) because the destination is unknown. (B) Golgi membranes continue via ER membranes (er) into the ONM. The ER contains 4 virus-like particles. (C) Details of panel B. (D) PNS, ER and Golgi complex form an entity in a BoHV-1 infected MDBK cell (D: This figure has been reproduced with permission of P. Wild et al., Micron 33, 2002, Elsevier). Bars $200 \mathrm{~nm}$.

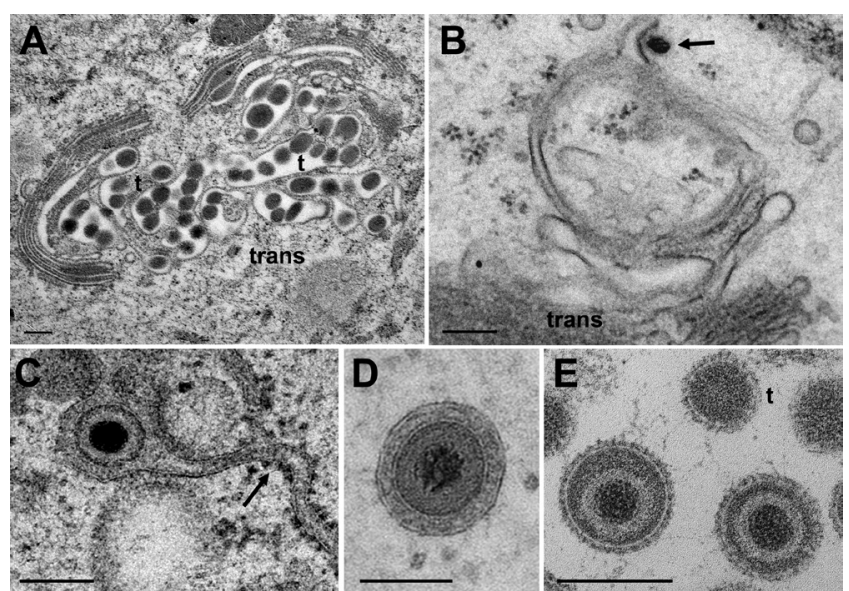

Figure 9. Golgi cisternae engulfing BoHV-1 virions at $20 \mathrm{hpi}$. Many of them are tangentially (t) sectioned. (B) Budding BoHV-1 capsid at a Golgi membrane of the cis-face (arrow). (C) HSV-1 virion in a Golgi cisterna that connects to the ER (arrow). Note the dense content within the ER and Golgi cisterna indicating little loss of material during processing. (D) Concentric vacuole derived by wrapping containing a single BoHV-1 virion. The space between viral envelope and vacuolar membrane is always filled in well preserved cells. (E) Virions in a large vacuole or cisterna exhibiting clearly spikes even in tangentially (t) sectioned virions. Bars: $200 \mathrm{~nm}$ 
Golgi complex in Figure 9A are more likely to represent cisternae rather than vacuoles because of their shape and location. The virions had gained access either by budding or by intraluminal transportation via ER-Golgi intermediates, as might be the case also in Figure 9C. Note that the viral envelope including spikes are covered by a dense layer in narrow Golgi cisternae (Figure 9C) whereas spikes are visible on virions in wide Golgi cisternae or large vacuoles (Figure 5 inset) and in the extracellular space (Figure 9E) as shown previously (Leuzinger et al., 2005; Wild et al., 2005). From the facts that virions are within ER and Golgi cisternae, and that the ONM continues via ER membranes into Golgi membranes forming an entity, we postulate that virions can be intraluminally transported from the PNS via ER into Golgi cisternae.

\section{ER-to-Golgi transitions in uninfected cells}

ER-to-Golgi transitions are not only established in infected cells, but also in cultured epithelial cells (Figure 10A) or in cells in organs, e.g. parathyroid gland, which was prepared by perfusion fixation (Wild et al., 1985) according to conventional protocols (Figure 10B). These observations suggest that ER to Golgi transitions may also serve as a direct transportation route e.g. for proteins to be finally released by exocytosis.

\section{Dataset 1. Raw images for Figure 1-Figure 5, Figure 8-Figure 10}

http://dx.doi.org/10.5256/f1000research.12252.d179644

Dataset 2. Raw values for Figure 6 and Figure 7

http://dx.doi.org/10.5256/f1000research.12252.d179645

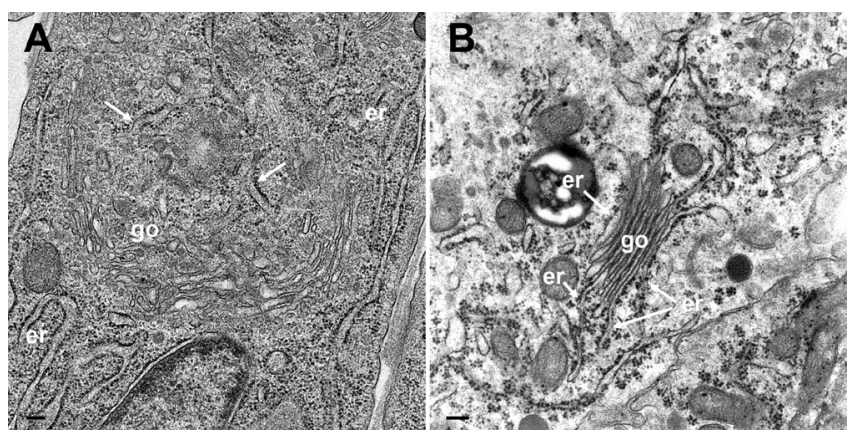

Figure 10. (A) TEM image of a cultured epithelial cell in which the Golgi complex is embedded in the ER. The ER membranes (arrows) run into the Golgi complex, close to a structure that probably represents a tangential section of the Golgi organizing center. (B) TEM image of a parathyroid cell prepared according to conventional protocols showing Golgi membranes (go) continuing into ER membranes (er). Bars: $200 \mathrm{~nm}$.

\section{Discussion}

The Golgi complex is among the first organelles that rapidly disintegrate during processing for electron microscopy after improper fixation and processing (Han et al., 2013; Wild et al., 2001). To minimize disintegration, we employed a technique that leads to improved retention of cellular material (Cope \& Williams, 1969; Weibull et al., 1984), and to improved spatial and temporal resolution (Mueller, 1992). This is especially important for analytical studies of cells in which the Golgi complex is involved in highly dynamic processes such as packaging of proteins into granules (Ellinger et al., 2010; Orci et al., 1981; Wild et al., 1982) in the secretory pathway, or envelopment of capsids and vacuole formation (Figure 11) for delivery of hundreds of virions to the cell periphery (Leuzinger et al., 2005; Wild et al., 2015; Wild et al., 2002). Because of the difficulties in preservation of the Golgi ultrastructure (Ellinger et al., 2010; Han et al., 2013; Wild et al., 2001), its three-dimensional structure is poorly understood. Cryo-FESEM revealed the Golgi complex to be a complex tightly packed structure. The membrane of the outermost cisternae may completely cover the cis-face. TEM also revealed that the Golgi complex is embedded in the ER system, with multiple membrane connections forming a Golgi-ER entity.

The Golgi complex fragments and disperses about 16 hpi with HSV-1 (Campadelli et al., 1993) adding additional difficulties for understanding Golgi function in herpes virus envelopment. To address the significance of the Golgi complex in virus envelopment and virus transportation, we thus investigated infected cells between 8 hpi (the approximate time of onset of envelopment) and 16 hpi. Our data clearly show that the Golgi complex is localized in a juxtanuclear position appearing as a compact entity by cryo-FESEM. Golgi membranes continue into ER membranes which in turn connect to the ONM forming a continuum between Golgi cisternae and PNS. Thus, the presence of virions within the PNS, ER cisternae and Golgi cisternae strongly suggests that the ER-to-Golgi transition is used as a direct intraluminal pathway to deliver virions from the PNS into Golgi cisternae (Figure 11, pathway 1). This idea is supported by the fact that about $80 \mathrm{HSV}-1$ virions per mean cell volume were within ER cisternae at 12 and 16 hpi but close to 300 by 24 hpi (Wild et al., 2015) suggesting that virus transportation out of the ER is inhibited after Golgi fragmentation (Campadelli et al., 1993). Virus transportation out of the ER is also drastically inhibited after BFA exposure. The ER delates and secretory protein transport from the ER to the Golgi complex is impeded after BFA treatment (Fujiwara et al., 1988; Misumi et al., 1986). Hence, the integrity of the Golgi complex is crucial for export of both secretory proteins and HSV-1 out of the ER suggesting that HSV-1 release from the ER to the Golgi complex follows a similar pathway as secretory proteins either by vesicle formation involving cop II (Klumperman, 2000) or equivalent, or via ER-Golgi transitions. 

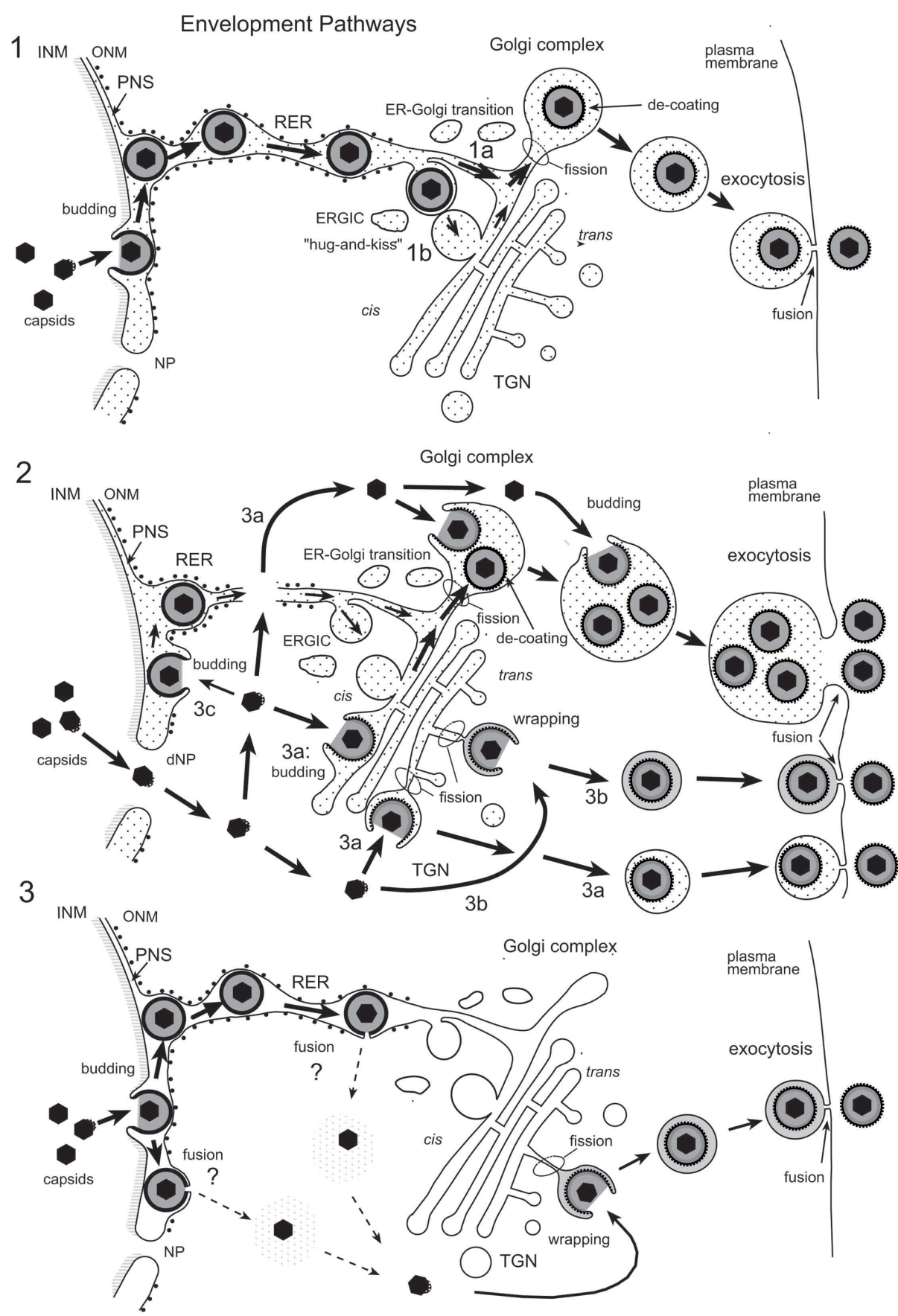

Figure 11. Schematic representation of proposed herpes virus envelopment pathways. (1) Capsids bud at the INM into the PNS acquiring tegument and an envelope covered with a dense coat. These perinuclear virions are transported into the RER and further via Golgi transitions (1a) or the ERGIC ("hug-and-kiss", 1b) into Golgi cisternae where they are packaged into transport vacuoles, which are detached from Golgi membranes by fission. The dense coat is shed off while vacuoles are transported to the cell periphery for exocytotic release of uncoated virions into the extracellular space. (2) Capsids gain direct access to the cytoplasmic matrix via dilated nuclear pores (dNP), and are transported to any site of the Golgi complex. They either bud into Golgi cisternae and vacuoles, respectively (2a) or are enveloped by a process designated wrapping (2b) that involves budding and concomitant formation of a small transport vacuole engulfing a single virion. Occasionally, capsids may bud at the OM or RER (2c), and the resulting virions are intraluminally transported as in pathway 1. (3) After budding at the INM, capsids and tegument of perinuclear virions are released into the cytoplasmic matrix via fusion of the viral envelopment (including dense coat) with the ONM (de-envelopment). Capsids are then re-enveloped at the trans Golgi network (TGN) by wrapping. Finally, vacuoles derived by fission from Golgi membranes transport virions to the cell periphery and release them into the extracellular space via exocytosis. The dense coat, which derived during the budding process at the INM and probably protects the viral envelope from fusion with membranes the virions are transported along, is shed of (de-coating) in transport vacuoles at latest when virions are released into the extracellular space. During budding at Golgi cisternae and vacuoles, a dense rim of tegument is closely attached to the inner layer of the viral envelope. No dense coat is formed so that spikes (glycoproteins) are readily seen in high resolution micrographs. 
According to the currently stressed herpes virus egress theory (Figure 11, pathway 3), formation of infectious herpes viruses follows a complicated uneconomic pathway involving primary envelopment by budding of capsids at the INM, de-envelopment of capsids by fusion of the viral envelope with the ONM releasing capsids and tegument into the cytoplasmic matrix, and re-envelopment by wrapping at the trans Golgi network. The interaction of the viral envelope with the ONM was described the first time in 1968 (Darlington \& Moss, 1968) and identified as budding of capsids from the cytoplasmic matrix into the PNS. About 30 years later, it was tried to prove that this process is fusion (Kopp et al., 2002; Naldinho-Souto et al., 2006; Skepper et al., 2001). Fact is that the phenotypes of the process taking place at the ONM are identical with those at the INM (Darlington \& Moss, 1968; Leuzinger et al., 2005; Wild et al., 2005; Wild et al., 2012) and that they show all characteristics of budding. Budding requires proteins that are able to induce positive and negative curvatures. Budding at the INM is driven by UL31/UL34 (Bigalke \& Heldwein, 2016; Bigalke \& Heldwein, 2017; Bigalke et al., 2014; Hagen et al., 2015). UL31 and UL34 are also present at the ONM even in cells infected with Us3 deletion mutants (Reynolds et al., 2002) those envelopes are unable to fuse with the ONM (Reynolds et al., 2002; Wisner et al., 2009). Therefore, the presence of UL31/UL34 at the ONM cannot be the result of membrane transportation from the INM to the ONM via budding and subsequent fusion as often used as arguments for the presence of viral proteins at the ONM. Furthermore, UL34 was shown to localize at the ER (Yamauchi et al., 2001) and that UL31 is required for its dislocation to the INM. Recently, it was accidentally proved that the virus interaction at the ONM and ER membranes is budding rather than fusion. Glycoproteins B and $\mathrm{H}(\mathrm{gB} / \mathrm{gH})$, members of the quartet responsible for cell entry (Turner et al., 1998), have been claimed to be responsible for fusion of the viral envelope with the ONM (Farnsworth et al., 2007). Electron microscopy strikingly revealed virus interactions with the ONM and ER membranes showing all characteristics of budding in cells infected with a $\mathrm{gB} / \mathrm{gH}$ deletion mutant. Since the viral envelope cannot fuse in the absence of $\mathrm{gB} / \mathrm{gH}$ the phenotypes shown in Figure 2 of this report (Farnsworth et al., 2007) represent undoubtedly various stages of capsids budding from the cytoplasmic matrix into the PNS and ER cisternae. Furthermore, in Vero cells infected with the $\mathrm{gB} / \mathrm{gH}$ deletion mutant, three times more virions were found in the cytoplasm compared to wild type infected Vero cells, and about a third in the extracellular space. Similar relations though less pronounced were found in other cell types absolutely implying another transportation route than that of de-envelopment by fusion of the viral envelope with the ONM.

Wrapping demands an enormous amount of membranes that would need to be provided to the TGN, which, to our knowledge, is not clear yet. However, capsids can be wrapped at diverse sides of the Golgi complex or can bud into Golgi cisternae and/or vacuoles via another pathway than wrapping. There are numerous reports showing HSV-1 virions in vacuoles and/or Golgi cisternae (Homman-Loudiyi et al., 2003; Leuzinger et al., 2005; Stannard et al., 1996; Sutter et al., 2012; Wild et al., 2015; Wild et al., 2002). Budding of capsids at various sites of Golgi membranes as well as virions in Golgi cisternae and vacuoles were also shown in pseudorabies virus infected cells (Klupp et al., 2008). These virions in all these vacuoles and/or Golgi cisternae did not arise by wrapping because wrapping results in a single virion in a concentric vacuole. They may have entered Golgi cisternae by budding into them or by intraluminal transportation via ER-to-Golgi transitions. Transient elements from cis and trans Golgi sides have been shown in various cells (Pavelka \& Roth, 2015). It was also suggested that the cis-Golgi approaches the ER and contacts the ER exit sites in the yeast Saccharomyces cerevisiae to capture cargo for transportation to the Golgi complex (Kurokawa et al., 2014). This 'hug-and-kiss' behavior could be another route to transfer virions, which are intraluminally transported to ER exit sites, into the Golgi cisternae.

In cells prepared for improved resolution, we found no valid arguments for de-envelopment by fusion of the viral envelope with the ONM. There are a number of facts that argue clearly against the de-envelopment theory. First, the morphology of the process taking place at the INM and ONM are identical showing all characteristics for budding (Darlington \& Moss, 1968; Leuzinger et al., 2005; Wild et al., 2005; Wild et al., 2012) but none for fusion (Haluska et al., 2006; Kanaseki et al., 1997) considering fundamentals of membrane bound transportation (Leabu, 2006; Peters et al., 2004; White, 1992). Second, virions have been repeatedly shown within ER cisternae (Gilbert et al., 1994; Granzow et al., 1997; Leuzinger et al., 2005; Radsak et al., 1996; Schwartz \& Roizman, 1969; Stannard et al., 1996; Sutter et al., 2012; Wild et al., 2002). To reach this location, either virions need to be transported from the PNS into the ER, or capsids have to bud from the cytoplasmic matrix into the ER. If virions can be intraluminally transported out of the PNS the viral envelope must be protected from fusion with membranes the virions are transported along. If capsids have the ability to bud at ER membranes capsids are very likely to be able to bud at the ONM since the ONM is part of the ER. Third, virions can accumulate to large numbers in the PNS, e.g. in the absence of the protein kinase Us3 (Poon et al., 2006; Reynolds et al., 2002; Wild et al., 2015). Strangely enough, these virions are infective (Reynolds et al., 2002; Ryckman \& Roller, 2004; Wild et al., 2015) despite the inability of the envelope to fuse with the ONM (Wisner et al., 2009) clearly contradicting the theory that de- and re-envelopment is essential to become infective (Klupp et al., 2011). Fourth, the equivalent to budding is the formation of coated pits resulting in coated vesicles (Owen \& Luzio, 2000; Pearse et al., 2000). Coated vesicles derive e.g. from the plasma membrane and are transported towards the Golgi complex where they fuse with Golgi membranes (Orci et al., 1981). However, coated vesicles must be uncoated to gain the ability for fusion. The coat consists of clathrin that drives formation of coated pits and finally coated vesicles and protects them from fusion. Clathrin was claimed to be involved in envelopment of HSV-6 capsids at Golgi membranes together with viral proteins (Mori et al., 2008). Budding of HSV-1 capsids at the INM is driven by the nuclear envelopment complex, UL31/UL34, (Bigalke \& Heldwein, 2015; Bigalke et al., 2014; Hagen et al., 2015) located at the nuclear rim (Mou et al., 2009). 
Budding at the INM, ONM and ER membranes starts with deposition of dense substances that finally result in a dense coat at the viral envelop. The dense coat is readily seen on virions in the PNS, ER and, inconsistently, in Golgi cisternae and large vacuoles containing many virions. The dense coat suggests that it protects virions from fusion with membranes the virions is transported along but allows virus transportation from the PNS into ER and Golgi cisternae. However, in large Golgi cisternae and/or vacuoles, many virions are without dense coat. Instead, spikes are visible like at virions in the extracellular space. Budding at Golgi membranes takes place without dense coat formation.

\section{Conclusions}

Golgi membranes interconnect with ER membranes in cells infected with HSV-1, a Us3 deletion mutant thereof or with BoHV-1 as well as in uninfected cells. The ER continues into the ONM, that turns into the INM at sites of nuclear pores. Consequently, the PNS, ER and Golgi complex forms an entity that can be only visualized by TEM, either when the membranes of all three compartments are luckily hit in the same plane of a given section, or by 3D-reconstruction after imaging of serial sections, focused ion beam (FIB) microscopy or electron tomography. Fact is that virions are intraluminally transported out of the PNS into the ER. This implies that the viral envelope needs to be protected from fusion with the membranes the virions are transported along. Thus, the significance of the dense coat, which derives during budding of capsids at nuclear membranes, is protecting the viral envelope from fusion in a similar manner as clathrin protects coated vesicles from fusion. The ER-to-Golgi transitions, virions in Golgi cisternae with a similar dense coat as virions in the
PNS and ER, and inhibition of virion transportation out of the PNS and ER after disruption of the Golgi complex by BFA, strongly suggest that virions are intraluminally transported from the PNS through the ER into Golgi cisternae. We propose that this is the only pathway for virions out of the PNS, and that capsids gain direct access to the cytoplasm from the nucleus via dilated nuclear pores and impaired nuclear envelope.

\section{Data availability}

Dataset 1: Raw images for Figure 1-Figure 5, Figure 8-Figure 10. DOI, 10.5256/f1000research.12252.d179644 (Wild et al., 2017a)

Dataset 2: Raw values for Figure 6 and Figure 7. DOI, 10.5256/ f1000research.12252.d179645 (Wild et al., 2017b)

\section{Competing interests}

No competing interests were disclosed.

\section{Grant information}

This study was supported by the Foundation for Scientific Research at the University of Zürich, Switzerland.

The funders had no role in study design, data collection and analysis, decision to publish, or preparation of the manuscript.

\section{Acknowledgments}

We thank Bernard Roizman, University of Chicago, for providing the Us3 deletion mutant.
Albecka A, Laine RF, Janssen AF, et al.: HSV-1 Glycoproteins Are Delivered to Virus Assembly Sites Through Dynamin-Dependent Endocytosis. Traffic. 2016; 17(1): 21-39.

PubMed Abstract | Publisher Full Text | Free Full Text

Ben-Tekaya $\mathrm{H}$, Miura K, Pepperkok R, et al:: Live imaging of bidirectional traffic from the ERGIC. J Cell Sci. 2005; 118(Pt 2): 357-367.

PubMed Abstract | Publisher Full Text

Bigalke JM, Heldwein EE: Structural basis of membrane budding by the nuclear egress complex of herpesviruses. EMBO J.2015; 34(23): 2921-2936.

PubMed Abstract | Publisher Full Text | Free Full Text

Bigalke JM, Heldwein EE: Nuclear Exodus: Herpesviruses Lead the Way. Annu Rev Virol. 2016; 3(1): 387-409.

PubMed Abstract | Publisher Full Text | Free Full Text

Bigalke JM, Heldwein EE: Have NEC Coat, Will Travel: Structural Basis of Membrane Budding During Nuclear Egress in Herpesviruses. Adv Virus Res. 2017: 97: 107-141.

PubMed Abstract | Publisher Full Text | Free Full Text

Bigalke JM, Heuser T, Nicastro D, et al.: Membrane deformation and scission by the HSV-1 nuclear egress complex. Nat Commun. 2014; 5: 4131.

PubMed Abstract | Publisher Full Text | Free Full Text

Bonifacino JS, Glick BS: The mechanisms of vesicle budding and fusion. Cell. 2004; 116(2): 153-166.

PubMed Abstract | Publisher Full Text

Borchers K, Oezel M: Simian agent 8 (SA8): morphogenesis and ultrastructure. Zentralbl Bakteriol. 1993; 279(4): 526-536.

PubMed Abstract | Publisher Full Text

Campadelli G, Brandimarti R, Di Lazzaro C, et al.: Fragmentation and dispersal of Golgi proteins and redistribution of glycoproteins and glycolipids processed through the Golgi apparatus after infection with herpes simplex virus 1.
Proc Natl Acad Sci U S A. 1993; 90(7): 2798-2802. PublMed Abstract | Publisher Full Text | Free Full Text

Chatterjee S, Sarkar S: Studies on endoplasmic reticulum--Golgi complex cycling pathway in herpes simplex virus-infected and brefeldin A-treated human fibroblast cells. Virology. 1992; 191(1): 327-337.

PubMed Abstract | Publisher Full Text

Cheung P, Banfield BW, Tufaro F: Brefeldin A arrests the maturation and egress of herpes simplex virus particles during infection. $J$ Virol. 1991; 65(4): 1893-1904.

PubMed Abstract | Publisher Full Text | Free Full Text

Cope GH, Williams MA: Quantitative studies on the preservation of choline and ethanolamine phosphatides during tissue preparation for electron microscopy. I. Glutaraldehyde, osmium tetroxide, Araldite methods. J Microsc. 1969; 90(1):

31-46.

PubMed Abstract | Publisher Full Text

Darlington RW, Moss LH 3rd: Herpesvirus envelopment. J Virol. 1968; 2(1): 48-55. PubMed Abstract | Free Full Text

Ellinger A, Vetterlein M, Weiss $C$, et al.: High-pressure freezing combined with in vivo-DAB-cytochemistry: a novel approach for studies of endocytic compartments. J Struct Biol. 2010; 169(3): 286-293.

PubMed Abstract | Publisher Full Text

Emr S, Glick BS, Linstedt AD, et al.: Journeys through the Golgi--taking stock in a new era. J Cell Biol. 2009; 187(4): 449-453.

PubMed Abstract | Publisher Full Text | Free Full Text

Farnsworth A, Wisner TW, Webb M, et al:: Herpes simplex virus glycoproteins $\mathrm{gB}$ and $\mathrm{gH}$ function in fusion between the virion envelope and the outer nuclear membrane. Proc Natl Acad Sci U S A. 2007; 104(24): 10187-10192. PubMed Abstract | Publisher Full Text | Free Full Text

Fujiwara T, Oda K, Yokota S, et al.: Brefeldin A causes disassembly of the 
Golgi complex and accumulation of secretory proteins in the endoplasmic reticulum. J Biol Chem. 1988; 263(34): 18545-18552. PubMed Abstract

Gilbert R, Ghosh K, Rasile L, et al:: Membrane anchoring domain of herpes simplex virus glycoprotein $\mathrm{gB}$ is sufficient for nuclear envelope localization. $J$ Virol. 1994; 68(4): 2272-2285.

PubMed Abstract | Free Full Text

Granzow $\mathrm{H}$, Weiland $\mathrm{F}$, Jöns $\mathrm{A}$, et al:: Ultrastructural analysis of the replication cycle of pseudorabies virus in cell culture: a reassessment. J Virol. 1997; 71(3): 2072-2082.

PubMed Abstract | Free Full Text

Hagen C, Dent KC, Zeev-Ben-Mordehai T, et al.: Structural Basis of Vesicle Formation at the Inner Nuclear Membrane. Cell. 2015; 163(7): 1692-1701. PubMed Abstract | Publisher Full Text | Free Full Text

Haluska CK, Riske KA, Marchi-Artzner V, et al:: Time scales of membrane fusion revealed by direct imaging of vesicle fusion with high temporal resolution.

Proc Natl Acad Sci U S A. 2006; 103(43): 15841-15846.

PubMed Abstract | Publisher Full Text | Free Full Text

Han HM, Bouchet-Marquis C, Huebinger J, et al:: Golgi apparatus analyzed by

cryo-electron microscopy. Histochem Cell Biol. 2013; 140(4): 369-381.

PubMed Abstract | Publisher Full Text | Free Full Text

Harrison SC: Viral membrane fusion. Virology. 2015; 479-480: 498-507.

PubMed Abstract | Publisher Full Text | Free Full Text

Hauri HP, Schweizer A: The endoplasmic reticulum-Golgi intermediate compartment. Curr Opin Cell Biol. 1992; 4(4): 600-608.

PubMed Abstract | Publisher Full Text

Hess MW, Müller M, Debbage PL, et al.: Cryopreparation provides new insight into the effects of brefeldin A on the structure of the HepG2 Golgi apparatus.

J Struct Biol. 2000; 130(1): 63-72.

PubMed Abstract | Publisher Full Text

Hollinshead M, Johns HL, Sayers CL, et al.: Endocytic tubules regulated by Rab GTPases 5 and 11 are used for envelopment of herpes simplex virus. EMBO J. 2012; 31(21): 4204-4220.

PubMed Abstract | Publisher Full Text | Free Full Text

Homman-Loudiyi M, Hultenby K, Britt W, et al.: Envelopment of human cytomegalovirus occurs by budding into Golgi-derived vacuole compartments positive for $\mathrm{gB}$, Rab 3 , trans-golgi network 46 , and mannosidase II. [erratum appears in J Virol. Arch. 2003 Jul; 77 (14): 8179]. J Virol. 2003; 77(5): 3191-3203. PubMed Abstract | Publisher Full Text | Free Full Text

Jahn R, Lang T, Südhof TC: Membrane fusion. Cell. 2003; 112(4): 519-533. PubMed Abstract | Publisher Full Tex

Jensen HL, Norrild B: Temporal morphogenesis of herpes simplex virus type

1-infected and brefeldin A-treated human fibroblasts. Mol Med. 2002; 8(4): 210-224.

PubMed Abstract | Free Full Text

Kanaseki T, Kawasaki K, Murata M, et al.: Structural features of membrane fusion between influenza virus and liposome as revealed by quick-freezing electron microscopy. J Cell Biol. 1997; 137(5): 1041-1056.

PubMed Abstract | Publisher Full Text | Free Full Text

Klumperman J: Transport between ER and Golgi. Curr Opin Cell Biol. 2000; 12(4): 445-449.

PubMed Abstract | Publisher Full Text

Klupp B, Altenschmidt J, Granzow $\mathrm{H}$, et al: Glycoproteins required for entry are not necessary for egress of pseudorabies virus. J Virol. 2008; 82(13): 6299-6309. PubMed Abstract | Publisher Full Text | Free Full Text

Klupp BG, Granzow H, Mettenleiter TC: Nuclear envelope breakdown can substitute for primary envelopment-mediated nuclear egress of herpesviruses. J Virol. 2011; 85(16): 8285-8292.

PubMed Abstract | Publisher Full Text | Free Full Text

Kopp M, Klupp BG, Granzow H, et al:: Identification and characterization of the pseudorabies virus tegument proteins UL46 and UL47: role for UL47 in virion morphogenesis in the cytoplasm. J Virol. 2002; 76(17): 8820-8833.

PubMed Abstract | Publisher Full Text | Free Full Text

Kurokawa K, Okamoto M, Nakano A: Contact of cis-Golgi with ER exit sites executes cargo capture and delivery from the ER. Nat Commun. 2014; 5: 3653 . PubMed Abstract | Publisher Full Text | Free Full Text

Leabu M: Membrane fusion in cells: molecular machinery and mechanisms. J Cell Mol Med. 2006; 10(2): 423-427.

PubMed Abstract | Publisher Full Text | Free Full Text

Lee KK: Architecture of a nascent viral fusion pore. EMBO J. 2010; 29(7): 1299-1311.

PubMed Abstract | Publisher Full Text | Free Full Text

Leuzinger $\mathrm{H}$, Ziegler $\mathrm{U}$, Schraner EM, et al:: Herpes simplex virus 1 envelopment follows two diverse pathways. $J$ Virol. 2005; 79(20): 13047-13059.

PubMed Abstract | Publisher Full Text | Free Full Text

Lippincott-Schwartz J: An evolving paradigm for the secretory pathway? Mol BiOl Cell. 2011; 22(21): 3929-3932.

PubMed Abstract | Publisher Full Text | Free Full Text

Lippincott-Schwartz J, Donaldson JG, Schweizer A, et al:: Microtubule-dependent retrograde transport of proteins into the ER in the presence of brefeldin A

suggests an ER recycling pathway. Cell. 1990; 60(5): 821-836.

PubMed Abstract | Publisher Full Text

Lippincott-Schwartz J, Yuan LC, Bonifacino JS, et al.: Rapid redistribution of
Golgi proteins into the ER in cells treated with brefeldin A: evidence for membrane cycling from Golgi to ER. Cell. 1989; 56(5): 801-813.

PubMed Abstract | Publisher Full Text

Longnecker R, Roizman B: Clustering of genes dispensable for growth in culture in the S component of the HSV-1 genome. Science. 1987; 236(4801): 573-576. PubMed Abstract | Publisher Full Text

Maric M, Haugo AC, Dauer W, et al:: Nuclear envelope breakdown induced by herpes simplex virus type 1 involves the activity of viral fusion proteins. Virology. 2014; 460-461: 128-137.

PubMed Abstract | Publisher Full Text | Free Full Text

Mayer A: Membrane fusion in eukaryotic cells. Annu Rev Cell Dev Biol. 2002; 18: 289-314.

PubMled Abstract | Publisher Full Text

Mettenleiter TC, Klupp BG, Granzow H: Herpesvirus assembly: a tale of two membranes. Curr Opin Microbiol. 2006; 9(4): 423-429.

PubMed Abstract | Publisher Full Text

Mettenleiter TC, Müller F, Granzow H, et al.: The way out: what we know and do not know about herpesvirus nuclear egress. Cell Microbiol. 2013; 15(2): 170-8. PubMed Abstract | Publisher Full Text

Misumi Y, Misumi Y, Miki K, et al.: Novel blockade by brefeldin A of intracellular transport of secretory proteins in cultured rat hepatocytes. J Biol Chem. 1986; 261(24): 11398-11403.

PubMed Abstract

Mori $Y$, Koike M, Moriishi E, et al: Human herpesvirus- 6 induces MVB formation, and virus egress occurs by an exosomal release pathway. Traffic. 2008; $9(10)$ 1728-1742.

PubMed Abstract | Publisher Full Text | Free Full Text

Mou F, Wills $E$, Baines JD: Phosphorylation of the $U \mathbf{~} 31$ protein of herpes simplex virus 1 by the $U_{s}$-encoded kinase regulates localization of the nuclear envelopment complex and egress of nucleocapsids. J Virol. 2009; 83(10): 5181-5191.

PubMed Abstract | Publisher Full Text | Free Full Text

Mueller M: The integrating power of cryofixation-based electron microscopy in biology. Acta Microscopica. 1992; 1: 37-46.

Naldinho-Souto R, Browne $\mathrm{H}$, Minson T: Herpes simplex virus tegument protein VP16 is a component of primary enveloped virions. J Virol. 2006; 80(5): 2582-4. PubMed Abstract | Publisher Full Text | Free Full Text

Orci L, Montesano R, Perrelet A: Exocytosis-endocytosis as seen with morphological probes of membrane organization. Methods Cell Biol. 1981; 23 : 283-300.

PubMed Abstract | Publisher Full Tex

Owen DJ, Luzio JP: Structural insights into clathrin-mediated endocytosis. Curr Opin Cell Biol. 2000; 12(4): 467-474.

PubMed Abstract | Publisher Full Text

Palade G: Intracellular aspects of the process of protein synthesis. Science. 1975; 189(4200): 347-358.

PubMed Abstract | Publisher Full Tex

Pavelka M, Roth J: Functional ultrastructure: atlas of tissue biology and pathology. Springer Vienna. 2015; 57-77.

Publisher Full Text

Pearse BM, Smith CJ, Owen DJ: Clathrin coat construction in endocytosis. Curr Opin Struct Biol. 2000; 10(2): 220-228.

PubMed Abstract | Publisher Full Text

Peters C, Baars TL, Bühler S, et al:: Mutual control of membrane fission and fusion proteins. Cell. 2004; 119(5): 667-678.

PubMed Abstract | Publisher Full Text

Polishchuk RS, Mironov AA: Structural aspects of Golgi function. Cell Mol Life Sci. 2004; 61(2): 146-158

PubMed Abstract | Publisher Full Text

Poon AP, Benetti L, Roizman B: $U_{s} 3$ and $U_{s} 3.5$ protein kinases of herpes simplex virus 1 differ with respect to their functions in blocking apoptosis and in virion maturation and egress. J Virol. 2006; 80(8): 3752-3764.

PubMed Abstract | Publisher Full Text | Free Full Text

Purves FC, Longnecker RM, Leader DP, et al:: Herpes simplex virus 1 protein kinase is encoded by open reading frame US 3 which is not essential for virus growth in cell culture. $J$ Virol. 1987; 61(9): 2896-2901.

PubMed Abstract | Free Full Text

Radsak K, Eickmann M, Mockenhaupt T, et al: Retrieval of human

cytomegalovirus glycoprotein $B$ from the infected cell surface for virus envelopment. Arch Virol. 1996; 141(3-4): 557-572.

PubMed Abstract | Publisher Full Text

Reynolds AE, Wills EG, Roller RJ, et al:: Ultrastructural localization of the herpes simplex virus type $1 U_{L} 31, U_{L} 34$, and $U_{S} 3$ proteins suggests specific roles in primary envelopment and egress of nucleocapsids. $J$ Virol. 2002; 76(17): 8939-8952.

PubMed Abstract | Publisher Full Text | Free Full Text

Roizman B, Knipe DM, Whitley RJ: Herpes simplex viruses. In: Fields Virology. K D M, P M, Howley, editor. Wolters Kluver/Lipincott Wiliams \& Wilkins, Philadelphia. 2014; 2: 1823-1897.

Ryckman BJ, Roller RJ: Herpes simplex virus type 1 primary envelopment: UL34 protein modification and the US3-UL34 catalytic relationship. $J$ Virol. 2004; 78(1): 399-412.

PubMed Abstract | Publisher Full Text | Free Full Text 
Saraste J, Dale HA, Bazzocco S, et al:: Emerging new roles of the pre-Golgi intermediate compartment in biosynthetic-secretory trafficking. FEBS Lett. 2009; 583(23): 3804-3810.

PubMed Abstract | Publisher Full Text

Schwartz J, Roizman B: Concerning the egress of herpes simplex virus from infected cells: electron and light microscope observations. Virology. 1969; 38(1): 42-49.

PubMed Abstract | Publisher Full Text

Skepper JN, Whiteley A, Browne $\mathrm{H}$, et al:: Herpes simplex virus nucleocapsids mature to progeny virions by an envelopment --> deenvelopment --> reenvelopment pathway. J Virol. 2001; 75(12): 5697-5702.

PubMed Abstract | Publisher Full Text | Free Full Text

Stannard LM, Himmelhoch S, Wynchank S: Intra-nuclear localization of two envelope proteins, gB and gD, of herpes simplex virus. Arch Virol. 1996; 141(3-4): 505-524.

PubMed Abstract | Publisher Full Text

Sutter E, de Oliveira AP, Tobler K, et al:: Herpes simplex virus 1 induces de novo phospholipid synthesis. Virology. 2012; 429(2): 124-135.

PubMed Abstract | Publisher Full Text

Terasaki M, Campagnola P, Rolls MM, et al.: A new model for nuclear envelope breakdown. Mol Biol Cell. 2001; 12(2): 503-510.

PubMed Abstract | Publisher Full Text | Free Full Text

Turner A, Bruun B, Minson T, et al:: Glycoproteins gB, gD, and $\mathbf{g H g L}$ of herpes simplex virus type 1 are necessary and sufficient to mediate membrane fusion in a Cos cell transfection system. J Virol. 1998; 72(1): 873-875.

PubMed Abstract | Free Full Text

Vivero-Salmerón G, Ballesta J, Martínez-Menárguez JA: Heterotypic tubular connections at the endoplasmic reticulum-Golgi complex interface. Histochem Cell Biol. 2008; 130 (4): 709-717.

PubMed Abstract | Publisher Full Text

Weibull C, Villiger W, Carlemalm E: Extraction of lipids during freeze-

substitution of Acholeplasma laidlawii-cells for electron microscopy. J Microsc 1984; 134(Pt 2): 213-216.

PubMed Abstract | Publisher Full Text

Whealy ME, Card JP, Meade RP, et al: Effect of brefeldin A on alphaherpesvirus membrane protein glycosylation and virus egress. J Virol. 1991; 65(3): 1066-1081. PubMed Abstract | Free Full Text

White JM: Membrane fusion. Science. 1992; 258(5084): 917-924.

PubMed Abstract | Publisher Full Text

Wild P: Electron microscopy of viruses and virus-cell interactions. Methods Cell Biol. 2008; 88: 497-524.

PubMed Abstract | Publisher Full Tex

Wild P, Bitterli D, Becker M: Quantitative changes of membranes in rat parathyroid cells related to variations of serum calcium. Lab Invest. 1982; 47(4): 370-374. PubMed Abstract

Wild $\mathrm{P}$, Engels $\mathrm{M}$, Senn $\mathrm{C}$, et al: Impairment of nuclear pores in bovine herpesvirus 1-infected MDBK cells. J Virol. 2005; 79(2): 1071-1083.

PubMed Abstract | Publisher Full Text | Free Full Text

Wild P, Gloor S, Vetsch E: Quantitative aspects of membrane behavior in rat parathyroid cells after depression or elevation of serum calcium. Lab Invest. 1985; 52(5): 490-496.

PubMed Abstract

Wild $P$, Käch A, Lucas MS: High resolution scanning electron microscopy of the nuclear surface in herpes simplex virus 1 infected cells. In: Scanning electron microscopy for the life sciences. Schatten $\mathrm{H}$, editor. Cambridge University Press, New York, USA. 2012

Publisher Full Text

Wild $\mathrm{P}$, Leisinger $\mathrm{S}$, de Oliveira AP, et al:: Herpes simplex virus 1 Us 3 deletion mutant is infective despite impaired capsid translocation to the cytoplasm. Viruses. 2015; 7(1): 52-71.

PubMed Abstract | Publisher Full Text | Free Full Text

Wild P, Schraner EM, Adler H, et al:: Enhanced resolution of membranes in cultured cells by cryoimmobilization and freeze-substitution. Microsc Res Tech. 2001: 53(4): 313-321.

PubMed Abstract | Publisher Full Text

Wild $\mathrm{P}$, Schraner EM, Cantieni D, et al.: The significance of the Golgi complex in envelopment of bovine herpesvirus 1 (BHV-1) as revealed by cryobased electron microscopy. Micron. 2002; 33(4): 327-337.

PubMed Abstract | Publisher Full Text

Wild P, Senn C, Manera CL, et al.: Exploring the nuclear envelope of herpes simplex virus 1-infected cells by high-resolution microscopy. J Virol. 2009; 83(1): 408-419.

PubMed Abstract | Publisher Full Text | Free Full Text

Wild P, Kaech A, Schraner E, et al:: Dataset 1 in: Endoplasmic reticulum-toGolgi transitions upon herpes virus infection. F1000Research. 2017a. Data Source

Wild P, Kaech A, Schraner E, et al:: Dataset 2 in: Endoplasmic reticulum-toGolgi transitions upon herpes virus infection. F1000Research. 2017b. Data Source

Wisner TW, Wright CC, Kato A, et al: Herpesvirus gB-induced fusion between the virion envelope and outer nuclear membrane during virus egress is regulated by the viral US3 kinase. J Virol. 2009; 83(7): 3115-3126. PubMed Abstract | Publisher Full Text | Free Full Text

Yamauchi $Y$, Shiba $C$, Goshima F, et al: Herpes simplex virus type 2 UL34 protein requires UL31 protein for its relocation to the internal nuclear membrane in transfected cells. J Gen Virol 2001; 82(Pt 6): 1423-1428. PubMed Abstract | Publisher Full Text 


\section{Open Peer Review}

\section{Current Peer Review Status: ? ?}

\section{Version 1}

Reviewer Report 20 October 2017

https://doi.org/10.5256/f1000research.13264.r26714

(c) 2017 Griffiths G. This is an open access peer review report distributed under the terms of the Creative Commons Attribution License, which permits unrestricted use, distribution, and reproduction in any medium, provided the original work is properly cited.

\section{Gareth Griffiths}

Department of Biosciences, University of Oslo, Oslo, Norway

The paper by Wild and colleagues investigates the question of how Herpes virus assembles, a story that has been under debate for decades. This family of DNA viruses assemble in the nucleus and thereafter opinions differ as to how the virus gets out of the cell. The bulk of the data are based on high pressure freezing and freeze substitution and are of exceptionally high quality.

However, I had a hard time trying to figure out what the point of the paper was. The title suggests a virus-induced 'transition' between ER and Golgi. I don't understand what they conclude about the ER-Golgi nor what it means for the virus. Virus-induced implies a difference between infected and uninfected cells. The only image of an uninfected cell is the IF image in Fig 1. I don't see much difference in the pattern of GM-130 labeling, a marker of early Golgi compartments. They show no EM images of uninfected cell Golgi.

I had a serious problem also trying to understand how they could distinguish between the three models shown in Fig 11. I could not follow their logic. In my opinion to do this in a satisfactory was they would need to use host cell markers for the different Golgi compartments with use of some viral membrane markers. To be able to give directionality to their static images they would also need e.g an inducible system whereby they could block some stages of assembly and then release the block and follow kinetically where the accumulated viral proteins move to-with respect to host compartment markers. No compartment of the Golgi can be unequivocally identified without a marker.

The paper is not well described. For example the two virus mutants R7041 and R2641 are not well described. Why are they interesting? At the end of the discussion we learn that Us3 is a kinase. I could not find the interpretation for the acronym PNS, I eventually figured out it means peri nuclear space.

In the background part they describe how $\mathrm{gB} / \mathrm{gH}$ are reported as being essential for deenvelopment -the fusion step after budding into the nuclear envelope. When these proteins are missing one would expect enveloped virus to accumulate in the NE/ER. Yet they write- under this 
condition lots of capsids (without membrane) accumulate- and even infectious virus- so there must be an alternative exit route. As a question of logic the reader may ask: maybe the idea that these proteins are essential for de-envelopment is wrong?

Their description of the data on Us3 deletion mutants is not well explained.

The close connection between the ER and the Golgi in uninfected cells has been seen by many EM studies, going back to Albert Claude 1970, Rambourg and many others. It is also not true as stated in the $1^{\text {st }}$ paragraph of their Discussion that the Golgi 'disintegrates rapidly after improper fixation'-unless one forgets to add the aldehyde. They show a nice example of normal fixation in Fig 10B. I take issue with their claim that the 3D structure of the Golgi is poorly understood because of poor preservation. It is poorly understood because the organelle is complex and because one lacks systems to identify the different compartments in the same sections. I of course accept their claim that freeze substitution is the preferred option.

The images from BFA treated cells are impressive but I'm not sure that I get a real take home message from these experiments. The Golgi fuses back with the ER; there is accumulation of budded virions in the ER. I cannot see a clear interpretation.

The long paragraph in the beginning of page 10, dealing with the mutants is especially difficult to follow- e.g what does 'accidentally proved' mean?

Among the many issues I have with their three models (Fig 11) I ask: how do they distinguish between budding into a Golgi compartment and wrapping?

Model 1 is the only one devoid of A. cytoplasmic capsids and B. 'wrapping' profiles. Doesn't this rule out this model?

They poorly describe how they quantify virus particles in the different locations by EM. They must surely be referring the budding profiles to membrane length or compartment volume? (Page 4).

The Conclusion part is also very difficult to relate to.

Bottom of page 8 Dilates mis-spelt as 'Delates'.

Beginning of page 7 there is no word I know of in English - Exceptionalness'.

It is a pity that such technically nice work is not supported by clarity of writing.

Is the work clearly and accurately presented and does it cite the current literature? No

Is the study design appropriate and is the work technically sound?

No

Are sufficient details of methods and analysis provided to allow replication by others? No 


\section{If applicable, is the statistical analysis and its interpretation appropriate? No}

Are all the source data underlying the results available to ensure full reproducibility? No

\section{Are the conclusions drawn adequately supported by the results?}

No

Competing Interests: No competing interests were disclosed.

Reviewer Expertise: EM, cell biology, virology, cellular microbiology

I confirm that I have read this submission and believe that I have an appropriate level of expertise to confirm that it is of an acceptable scientific standard, however I have significant reservations, as outlined above.

Author Response 16 Feb 2018

Peter Wild, Institute of Virology, Zürich, Switzerland

Thank you for carefully reading the manuscript. You are right that the title may imply virusinduced formation of ER-to-Golgi transitions. However, it also may imply that viruses utilize existing transitions to transport virions from the PNS (abbreviation explained in introduction) into Golgi cisternae.

Golgi structure does not differ in uninfected and infected cells except that in infected cells Golgi cisternae contain virions, which is clearly shown in Figs. 3 and 8D. Cells harvested or fixed e.g. 6 hpi (hours post inoculation) does not necessarily mean, that the cell under study is infected or that the infection occurred at the very moment of inoculation. Therefore, the Golgi complexes shown in Figs 3 and 8D are not (or not yet) involved in envelopment or transportation although capsids have been produced yet not obviously released from the nucleus.

Immunolabelling does also not differ between uninfected and infected cells early in infection. However, the Golgi complex fragments about 16 hpi with wt HSV-1 as shown by Campadelli-Fiume et al., 1993. The reaction of the Golgi complex to infection with Us3 deletion mutant differs, which will be addressed in another article. The significance of Us3 will be included in introduction.

To use markers for the different Golgi compartments is an interesting issue. As shown in Fig. 1, the cis-Golgi disappears by $16 \mathrm{hpi}$, whereas the trans-Golgi became fragmented. In contrast, both cis- and trans-Golgi enlarge after infection with the Us3 deletion mutant. The significance of Us3 on the Golgi complex will be addressed elsewhere.

Markers of the viral envelope do not really help to locate the virions because they are present in the cytoplasm without virions, and even before the egress of virions starts (see e.g. de Oliveira et al., 2008).

For simplicity we will show in Fig. 11 only the 2 pathways we propose: 1) the intraluminal 
pathway via ER-to-Golgi transitions, and 2) the pathway involving capsid release via impaired envelope (starting by pore dilation) followed by envelopment at Golgi membranes either by wrapping or budding. We have published enough data to support the direct nucleus to cytoplasm capsid translocation as well as to differentiate between wrapping and budding at Golgi membranes and vacuolar membranes.

Numerous articles have been published using EM techniques and immunolabelling techniques on the light microscopic and EM level to try to support the idea of the envelopment - de-envelopment - re-envelopment pathway. Therefore, we do not repeat these experiments.

The idea of de-envelopment (fusion of the viral envelope of virions in the PNS with the ONM releasing capsids and tegument into the cytoplasmic matrix) came from Stackpole (1968) to explain the presence of naked capsids in the cytoplasm. However, there is no correct prove that the process taking place at the ONM is fusion.

Fact is that the processes taking place at the ONM is identical to that taking place at the INM showing all characteristics of budding as shown in detail earlier (Leuzinger et a., 2005).

Farnsworth et al., 2007 wanted to prove that the fusion proteins $\mathrm{gB} / \mathrm{gH}$ are responsible for the fusion of the viral envelope with the ONM leading to accumulations of virions in the PNS. They show in their Fig. 2. - now included in this paper as Fig. 12 - accumulation of virions in the PNS. "Accidentally" - or by mistake -, they overlooked about a dozen of virus interactions at the ONM. If these interactions were fusion virions would not have accumulated in the PNS. Consequently, 1) the process taking place at the ONM is budding not fusion, 2) $\mathrm{gB} / \mathrm{gH}$ play other roles in the egress pathway than mediating fusion of the viral envelope with the ONM, and 3) the envelopment - de-envelopment - re-envelopment theory is incorrect, as shown earlier using Us3 deletion mutants.

Us3 deletion mutants are infective although they almost completely accumulate in the PNS implying that Us3 null virions are not de-enveloped and re-enveloped. The same is true for the virions originating by budding at the INM after disintegration of the Golgi complex by BFA.

We have revised the manuscript implementing your suggestion, and simplified the complicated paragraph dealing with the false interpretation that $\mathrm{gB} / \mathrm{gH}$ promote fusion of the viral envelop with the ONM

The "simple" take home massages are: Virions derive by budding at the INM membrane are infective. The process taking place at the ONM is budding, not fusion. The de-envelopment re-envelopment theory is not valid.

Competing Interests: No competing interests were disclosed.

Author Response 14 Mar 2018

Peter Wild, Institute of Virology, Zürich, Switzerland

Comment: The paper by Wild and colleagues investigates the question of how Herpes virus 
assembles, a story that has been under debate for decades. This family of DNA viruses assemble in the nucleus and thereafter opinions differ as to how the virus gets out of the cell. The bulk of the data are based on high pressure freezing and freeze substitution and are of exceptionally high quality.

However, I had a hard time trying to figure out what the point of the paper was. The title suggests a virus-induced 'transition' between ER and Golgi. I don't understand what they conclude about the ER-Golgi nor what it means for the virus. Virus-induced implies a difference between infected and uninfected cells.

Response: Thank you for carefully reading the manuscript. You are right that the title may imply virus-induced formation of ER-to-Golgi transitions. However, it also may imply that viruses utilize existing transitions to transport virions from the PNS into Golgi cisternae. Virions are transported out of the PNS into ER cisternae. ER-Golgi transitions may thus be used to transport virions directly into Golgi cisternae. There are evidences that this idea is likely to be correct.

The only image of an uninfected cell is the IF image in Fig 1. I don't see much difference in the pattern of GM-130 labeling, a marker of early Golgi compartments. They show no EM images of uninfected cell Golgi.

Response: Golgi structure does not differ in uninfected and infected cells except that in infected cells Golgi cisternae contain virions, which is clearly shown in Figs. 3 and 8D. Cells harvested or fixed e.g. 6 hpi (hours post inoculation) does not necessarily mean, that the cell under study is infected or that the infection occurred at the very moment of inoculation. Therefore, the Golgi complexes shown in Figs 3 and 8D are not (or not yet) involved in envelopment or transportation although capsids might have been produced yet not obviously released from the nucleus and transported into the Golgi complex.

Immunolabelling does also not differ between uninfected and infected cells early in infection. However, the Golgi complex fragments about 16 hpi with wt HSV-1 as shown by Campadelli-Fiume et al., 1993. The Golgi complex enlarges after infection with Us3 deletion mutant, which will be addressed in another article. The revised Fig. shows the cis and trans Golgi after infection with HSV-1 and the Us3 deletion mutant.

I had a serious problem also trying to understand how they could distinguish between the three models shown in Fig 11. I could not follow their logic.

Response: We can only distinguish between two pathways: 1) Via budding at nuclear membranes followed by intraluminal transportation, and 2) capsid release via impaired nuclear envelope (that starts by pore dilation) followed by envelopment at Golgi membranes or membranes of the ER. This can be easily done based on the diverse phenotypes. For details see Leuzinger 2005, Wild 2002, 2005, 2009

Pathway 3 (which is omitted in the revised manuscript) is not our idea. The idea of deenvelopment (fusion of the viral envelope of virions in the PNS with the ONM releasing capsids and tegument into the cytoplasmic matrix) came from Stackpole (1968) to explain 
the presence of naked capsids in the cytoplasm. However, there is no correct prove that the process taking place at the ONM is fusion.

In my opinion to do this in a satisfactory was they would need to use host cell markers for the different Golgi compartments with use of some viral membrane markers.

Response: Where is no need to distinguish between Golgi compartments in this context. The question is: can virions be transported from the ER into the Golgi to what compartment ever. However, to use markers for the different Golgi compartments is an interesting issue considering Golgi fragmentation as shown in the revised Fig 1. (work is in progress). Markers of the viral envelope do not really help to locate the virions because they are present in the cytoplasm without virions, and even before the egress of virions starts (see e.g. de Oliveira et al., 2008).

To be able to give directionality to their static images they would also need e.g an inducible system whereby they could block some stages of assembly and then release the block and follow kinetically where the accumulated viral proteins move to-with respect to host compartment markers.

Response: As stated above, viral proteins are not useful to track virus particles. This is shown in the revised Fig. 1 showing the viral protein gB throughout the cytoplasm. To localize the 3 viral compartments (capsid, tegument, envelope) we constructed a triple coloured virus (Oliveira et al.2008).

No compartment of the Golgi can be unequivocally identified without a marker.

Response: In an image as shown in Fig. 9A one can easily identify the cis-and trans-face.

The paper is not well described. For example the two virus mutants R7041 and R2641 are not well described. Why are they interesting? At the end of the discussion we learn that Us3 is a kinase.

Response: The knowledge of the significance of Us3 is not important considering ER-toGolgi transitions. One important aspect is that Us3 downregulates phospholipid biosynthesis leading to enlargement of the Golgi complex if Us3 is absent as shown in the revised Fig. 1. The significance of Us3 on Golgi assembly early in infection is under study. R2641 is the repair mutant and does not need any explanation. The significance of Us3 is described in introduction of the revised manuscript.

I could not find the interpretation for the acronym PNS, I eventually figured out it means peri nuclear space.

Response: It was and still is in "introduction"

In the background part they describe how $\mathrm{gB} / \mathrm{gH}$ are reported as being essential for deenvelopment -the fusion step after budding into the nuclear envelope. When these proteins are missing one would expect enveloped virus to accumulate in the NE/ER. Yet they write- under this 
condition lots of capsids (without membrane) accumulate- and even infectious virus- so there must be an alternative exit route. As a question of logic the reader may ask: maybe the idea that these proteins are essential for de-envelopment is wrong?

Response: Yes, this idea is wrong. The process taking place at the outer nuclear membrane shows all characteristics of budding, none of fusion. It takes place in the absence of the fusion proteins $\mathrm{gB}$ and $\mathrm{gH}$ leading to accumulation of virions in the PNS. This is a clear indication for budding even for those who are not familiar with the fundamentals of membrane bound transportation. By the way, to distinguish between budding and fusion is as easy as to distinguish between the right and the left shoe.

Their description of the data on Us3 deletion mutants is not well explained.

Response: The only things we will show is ER-to-Golgi transitions, which we found often in cells infected with the Us3 deletion mutant. This has possibly something to do with the enlargement of the Golgi in the absence of Us3.

The close connection between the ER and the Golgi in uninfected cells has been seen by many EM studies, going back to Albert Claude 1970, Rambourg and many others.

Response: In my opinion, the question is not whether connections between ER and Golgi exist. The question is whether these connections are used for transport of cargo from the ER into Golgi cisternae. Considering the enormous amount of proteins produced and secreted in the exocrine pancreas (1.2 litter per day in humans) it seems to me likely that such a route exists.

It is also not true as stated in the $1^{\text {st }}$ paragraph of their Discussion that the Golgi 'disintegrates rapidly after improper fixation'-unless one forgets to add the aldehyde.

Response: This is certainly true. One can destroy the Golgi complex e.g. by using an inappropriate buffer during fixation. I know that you did excellent studies on Golgi structure and function. Unfortunately, there are too many papers published showing inadequate preservation of Golgi structure, including papers dealing with the egress of herpes viruses.

They show a nice example of normal fixation in Fig 10B. I take issue with their claim that the 3D structure of the Golgi is poorly understood because of poor preservation. It is poorly understood because the organelle is complex and because one lacks systems to identify the different compartments in the same sections. I of course accept their claim that freeze substitution is the preferred option.

Response: The complicated 3D structure plays certainly an important role that the Golgi is poorly understood.

The images from BFA treated cells are impressive but I'm not sure that I get a real take home message from these experiments. The Golgi fuses back with the ER; there is accumulation of budded virions in the ER. I cannot see a clear interpretation. 
Response: The accumulation of virions is the result of impaired transportation out of the PNS-ER compartment. Since the process taking place at the ONM is budding not fusion it is reasonable to assume that the intraluminal transport to the Golgi complex is impaired as was shown also for proteins. Furthermore, it is also an additional indication that the process at the ONM is not fusion because it is unlikely that disintegration of the Golgi would have an impact on the fusion process.

Us3 deletion mutants are infective although they almost completely accumulate in the PNS implying that Us3 null virions are not de-enveloped and re-enveloped. The same is true for the virions originating by budding at the INM, ONM and ER membranes after disintegration of the Golgi complex by BFA.

The real take home message is that the theory of de-re-envelopment is essential for production of infectious progeny virus is not valid.

The long paragraph in the beginning of page 10, dealing with the mutants is especially difficult to follow- e.g what does 'accidentally proved' mean?

Response: Accidentally means the following: Farnsworth et al., 2007 wanted to prove that the fusion proteins $\mathrm{gB} / \mathrm{gH}$ are responsible for the fusion of the viral envelope with the ONM leading to accumulations of virions in the PNS. They show in their Fig. 2. - now included in this paper as Fig. 12 - accumulation of virions in the PNS. "Accidentally" - or by mistake -, they overlooked about a dozen of virus interactions at the ONM and ER. If these interactions were fusion virions would not have accumulated in the PNS. Consequently, 1) the process taking place at the ONM is budding not fusion, 2) $\mathrm{gB} / \mathrm{gH}$ play other roles (if any?) in the egress pathway than mediating fusion of the viral envelope with the ONM, and 3) the envelopment - de-envelopment - re-envelopment theory is incorrect, as shown earlier using Us3 deletion mutants (see above).

Among the many issues I have with their three models (Fig 11) I ask: how do they distinguish between budding into a Golgi compartment and wrapping?

Response: Capsids can bud into vacuoles and cisternae of any size even if they contain already virions. During wrapping, the viral envelope and the vacuole are concomitantly formed. The result is a concentric vacuole containing a single virion. The space between virion and vacuolar membrane is filled by dense material that probably had driven the process. For details see Leuzinger et al. 2005 (JV), and Wild et al. 2002 (Micron).

Model 1 is the only one devoid of A. cytoplasmic capsids and B. 'wrapping' profiles. Doesn't this rule out this model?

Response: Model 1 is the intraluminal pathway: Capsids arise by budding at the INM, ONM or ER membranes and are intraluminally transported. The destination is considered likely to be Golgi cisternae via ER-Golgi transitions.

In model 2, capsids gain access to the cytoplasmic matrix via impaired nuclear envelope that starts by dilation of nuclear pores. See Leuzinger 2005, Wild 2005, 2009.

They poorly describe how they quantify virus particles in the different locations by EM. They must surely be referring the budding profiles to membrane length or compartment volume? (Page 4). 
Response: We expressed the number of virus particles per cellular profile. I know that this is not very appropriate. However, this was done by many other authors addressing herpes virus envelopment. Since it is obvious that virions accumulate in the PNS we consider the data to be sufficiently accurate. In the study about the significance of Us3 on the biosynthesis of phospholipids, we expressed the morphometric data per mean nuclear and cell volume, respectively (Wild et al., 2012).

The Conclusion part is also very difficult to relate to.

Bottom of page 8 Dilates mis-spelt as 'Delates'. Beginning of page 7 there is no word I know of in English - Exceptionalness'. It is a pity that such technically nice work is not supported by clarity of writing.

Response: It is difficult to write an article about a process that was misinterpreted for decades ignoring the fundamentals of membrane bound transportation, and that was pushed to an untouchable dogma.

We have revised the manuscript implementing your suggestion, and simplified the complicated paragraph dealing with the false interpretation that $\mathrm{gB} / \mathrm{gH}$ promote fusion of the viral envelop with the ONM. We also made clear in the conclusions that the significance of many viral proteins must be re-investigated in the light of correct interpretation of viralmembrane interactions.

Competing Interests: No competing interests were disclosed.

Reviewer Report 10 October 2017

https://doi.org/10.5256/f1000research.13264.r26712

(C) 2017 Grose C. This is an open access peer review report distributed under the terms of the Creative Commons Attribution License, which permits unrestricted use, distribution, and reproduction in any medium, provided the original work is properly cited.

\section{Charles Grose}

Virology Laboratory, Children's Hospital, University of Iowa, Iowa City, IA, 52242, USA

Professor Wild and his collaborators are well known for their expertise in electron microscopy. I also note that three other scientists who developed cryo-TEM won the Nobel Prize this year. The SEM and TEM images in this manuscript are excellent. I enjoyed reviewing their data. I have heard Professor Wild present his results at conferences. However, I can say upfront that most recent herpesvirus data appear to support pathway \#3 in Figure 11, which is not the pathway preferred by the Wild lab. For example, the authors do not consider that both the Elliott HSV lab and the C. Grose VZV lab have found evidence for Rab11 on the vesicles that transport enveloped virus. If the above two labs are correct, the pathway \#1 in Figure 11 cannot be completely correct because the drawings do not include the endocytic pathway. Thus, the experiment requested in Comment 6 needs to be performed to resolve this question. Overall, the suggestion is made that the Wild lab 
take a look at some of the VZV articles and include them in their discussion, even if the Wild lab disagree with the conclusions of the VZV lab.

1. Figure 1. Confocal microscopy of Vero cells. The text states that both WT and mutant virus were tested but only one virus is shown in Figure 1. Which virus is shown? If only WT virus is shown, may wish to add confocal with mutant virus.

2. Figures 4 and 5. Virions in ER cisternae. The C. Grose lab has published several articles about VZV encapsidation, VZV capsid transport from nucleus to cytoplasm and subsequent envelopment. These articles should be reviewed and cited by Wild et al. First of all, Wild should show us whether he finds viral particles between the INM and the ONM. For VZV, Harson and Grose (1995) have clearly shown that capsids with a thin envelope can be found between the INM and the ONM. See Harson and Grose, Figure 5, panels C, D and E. Note increase in diameter of particle between panels $\mathrm{C}$ and $\mathrm{E}$. Panel $\mathrm{F}$ is important because panel F shows a thin-enveloped particle still within the ER cisternae and clearly beyond the ONM. Thus, the VZV micrograph agrees with the data from Wild about "Virions are within ER cisternae."

3. Data not shown by Wild lab. Harson and Grose have shown that VZV capsids without a thin envelope can be found in the cytoplasm. The capsids do not appear to be within any Golgi derived compartment. See Figure 6 panel A, (Harson \& Grose, 1995). This micrograph provides evidence against the Wild hypothesis that herpesviruses are always retained within compartments derived from the ER or Golgi. There is one micrograph in the Wild manuscript that appears to resemble the VZV micrograph. See Wild manuscript Figure 9B, which shows a BoHV capsid (without a thin envelope) in the cytoplasm adjacent to a Golgi (or ER/Golgi) membrane. This single BoHV micrograph would seem to invalidate the Wild hypothesis that BoHV always is transported within ER or Golgi compartments?

4. Differences between viral particles in ER cisternae and viral particles in vesicles near the outer cell membrane. As noted above, data from the Grose lab agree with data from the Wild lab that viral particles are found in ER cisternae. But the Grose lab finds differences between particles in ER cisternae and particles in vesicles near the outer cell membrane. ER cistern are irregularly shaped. Particles within ER cisternae have a thin envelope without an obvious electron dense outer coat (presumably the viral glycoproteins). Vesicles containing viral particles near the outer cell membrane often are circular with a single outer membrane. See Figure 8 panel A in Harson \& Grose (1995), for a clear VZV example. The vesicle contains 4 particles, 2 of which are perfectly enveloped, with clearly defined capsid, tegument and envelope with electron-dense outer coat. These particles are slightly larger in diameter than the thin-enveloped particles seen in the irregular ER cisternae. The VZ virions in the circular vesicles are similar to the BoHV virions shown by Wild in his Figure 9 panels $D$ and $\mathrm{E}$. In other words, there clearly are two types of enveloped particles: particles with thinenvelope and particles with a thicker electron-dense envelope.

5. Virions are within Golgi cistern? Wild discusses viral particles with spikes and viral particles without obvious spikes. Spikes presumably represent mature glycoproteins. One possibility that Wild has not considered is that viral particles may be routed in different pathways. Some viral particles may enter the large Golgi-like cisternae. Other viral particles may be wrapped in individual vesicles. Why does there need to be a single pathway for all 
viral particles?

6. Lack of data about endocytic or autophagy pathways. There are now HSV and VZV papers that provide evidence for involvement of the endocytic and/or autophagy pathways in viral egress. The Elliott lab has shown that both Rab5 and Rab11 are involved in the final envelopment process for HSV. Further, they did not find co-localization of capsids with the TGN marker TGN46. See Hollinshead et al. 2012. The C. Grose lab confirmed that a fraction of purified VZ virions were positive for the Rab11 protein, presumably because the purified virions retained remnants of a Rab11-positive vesicle. See VZV article by Buckingham et al , 2016. The C. Grose lab also found the LC3-II protein in the same purified virion fraction and hypothesized that the virions were housed in amphisome-like vesicles, which contain both Rab11 and LC3-II proteins in their membrane. The fact that a HSV lab and a VZV lab both found Rab11 in the virion greatly strengthens the observation. These data are presented because they suggested that the Wild lab cannot determine the origin of the vesicles containing either HSV or BoHV virions by using only TEM and SEM. The Wild lab will need to use either immuno-TEM or alternatively isolate the HSV and BoHV particles, then examine them for proteins such as Rab11 and LC3-II by immunoblotting.

7. Figure 11. Schematic drawings. If the Elliott lab and the Grose lab are correct that purified HSV or VZV contain Rab11 protein, then schematic pathway \#1 in Figure 11 cannot be correct. Also, if the Elliott lab and the Grose lab are correct, then secondary envelopment must involve an intersection of the virus with a pathway outside of the ER/Golgi pathway. Strongly suggest that the Wild lab investigate whether any of the vacuoles that contain either HSV or BoHV are positive for the Rab11 protein. Electron microscopy alone is not sufficient.

8. Figure 7. Virus titers. cell by endocytosis. The titers at 8hpi probably represent viral particles formed after some actual HSV glycoprotThe data about the different titers with and without BFA may need re-interpretation. The titer is much lower when BFA was added at $5 \mathrm{hpi}$. Most of these particles would be capsids and capsids with thin-envelopes. A titer of $1000 \mathrm{PFU} / \mathrm{ml}$ seems reasonable for capsids, which could enter a ein biosynthesis. Some VZV glycoproteins undergo their biosynthesis within 2 hours. See article from Grose lab by Yao et al, 1993. Presumably HSV glycoproteins are synthesized at the same rate. Therefore, addition of BFA at 8 hpi would not prevent formation of substantial amounts of HSV glycoproteins, which would allow envelopment of viral particles, even by $8 \mathrm{hpi}$. In other words, I do not think that the BFA experiments add much weight to the arguments about which pathway HSV takes

9. Bovine herpesvirus data. I do find inclusion of the BoHV micrographs to be informative. The BoHV data appear to resemble the VZV data more closely than the HSV data. Remember that BoHV is a member of the varicellovirus subfamily.

10. Schematic pathway for VZV trafficking. Please take the time to look over the VZV pathway illustrated in Figure 8 , in article by Buckingham et al, 2016. It resembles pathway \#3 by the Wild group.

\section{References}

1. Harson R, Grose C: Egress of varicella-zoster virus from the melanoma cell: a tropism for the 
melanocyte.J Virol. 1995; 69 (8): 4994-5010 PubMed Abstract

2. Hollinshead M, Johns HL, Sayers CL, Gonzalez-Lopez C, et al.: Endocytic tubules regulated by Rab GTPases 5 and 11 are used for envelopment of herpes simplex virus.EMBO J. 2012; 31 (21): 4204-20 PubMed Abstract | Publisher Full Text

3. Buckingham EM, Jarosinski KW, Jackson W, Carpenter JE, et al.: Exocytosis of Varicella-Zoster Virus Virions Involves a Convergence of Endosomal and Autophagy Pathways.J Virol. 2016; 90 (19): 8673-85 PubMed Abstract | Publisher Full Text

4. Yao Z, Jackson W, Forghani B, Grose C: Varicella-zoster virus glycoprotein gpI/gpIV receptor: expression, complex formation, and antigenicity within the vaccinia virus-T7 RNA polymerase transfection system.J Virol. 1993; 67 (1): 305-14 PubMed Abstract

Is the work clearly and accurately presented and does it cite the current literature? Partly

Is the study design appropriate and is the work technically sound? Partly

Are sufficient details of methods and analysis provided to allow replication by others? Yes

If applicable, is the statistical analysis and its interpretation appropriate?

Not applicable

Are all the source data underlying the results available to ensure full reproducibility? Yes

Are the conclusions drawn adequately supported by the results?

No

Competing Interests: No competing interests were disclosed.

Reviewer Expertise: Varicella zoster virus

I confirm that I have read this submission and believe that I have an appropriate level of expertise to confirm that it is of an acceptable scientific standard, however I have significant reservations, as outlined above.

Author Response 14 Mar 2018

Peter Wild, Institute of Virology, Zürich, Switzerland

Professor Wild and his collaborators are well known for their expertise in electron microscopy. I also note that three other scientists who developed cryo-TEM won the Nobel Prize this year. The SEM and TEM images in this manuscript are excellent. I enjoyed reviewing their data. I have heard Professor Wild present his results at conferences. However, I can say upfront that most recent herpesvirus data appear to support pathway \#3 in Figure 11, which is not the pathway preferred by the Wild lab. For example, the authors do not consider that both the Elliott HSV lab 
and the C. Grose VZV lab have found evidence for Rab11 on the vesicles that transport enveloped virus. If the above two labs are correct, the pathway \#1 in Figure 11 cannot be completely correct because the drawings do not include the endocytic pathway. Thus, the experiment requested in Comment 6 needs to be performed to resolve this question. Overall, the suggestion is made that the Wild lab take a look at some of the VZV articles and include them in their discussion, even if the Wild lab disagree with the conclusions of the VZV lab.

Response: Thank you for the compliment. It is great honour to have become influenced by Jacques Dubochet, one of the Nobel prize winners on cryo-TEM. I am also very grateful for the impact of another Nobel prize winner, George Palade, whose laureate speech entitled "Variation on a common theme in the secretory pathway" published in Science,1975, is still a must to be read by people working in this field, including herpes virologists.

The intention of this work is to demonstrate connectivity between the PNS and the Golgi complex that may be used as a direct transport pathway for virions derived by budding at nuclear membranes. Budding at nuclear membranes followed by intraluminal transport is referred to as pathway 1 .

That does not mean that our lab prefers pathway 1 . We also showed that capsids gain access to the cytoplasmic matrix via impaired nuclear pores and impaired nuclear envelope, respectively. These capsids follow envelopment pathway 2 . In this pathway, the endocytic pathway will be included (we did not because, we shall discuss it in detail in another manuscript). Pathway 3 is obsolete, because the process at the outer nuclear membrane is budding not fusion as accidentally proved by Farnsworth et all, 2007, overlooking the process taking place at the ONM (see Fig.12).

Figure 1. Confocal microscopy of Vero cells. The text states that both WT and mutant virus were tested but only one virus is shown in Figure 1. Which virus is shown? If only WT virus is shown, may wish to add confocal with mutant virus.

Response: The location of the Golgi complex depends on the cell, not on the virus. Nevertheless, we included micrographs of Golgi labelled with antibodies against the cis and the trans face in cells infected with HSV-1 and the Us3 deletion mutant thereof.

Fragmentation of the Golgi complex depends on the virus. E.g. in Us3 deletion mutant infected cells, the Golgi complex enlarges, A manuscript addressing the significance of Us3 on the Golgi complex is in progress.

Figures 4 and 5. Virions in ER cisternae. The C. Grose lab has published several articles about VZV encapsidation, VZV capsid transport from nucleus to cytoplasm and subsequent envelopment. These articles should be reviewed and cited by Wild et al. First of all, Wild should show us whether he finds viral particles between the INM and the ONM.

Response: We have shown many times virions between the INM an ONM as well as in adjacent cisternae. However, we never found virions with a thin envelope. This might be related to the different fixation and preparation procedure.

For VZV, Harson and Grose (1995) have clearly shown that capsids with a thin envelope can be found between the INM and the ONM. See Harson and Grose, Figure 5, panels C, D and E. Note 
increase in diameter of particle between panels $C$ and $E$. Panel $F$ is important because panel $F$ shows a thin-enveloped particle still within the ER cisternae and clearly beyond the ONM. Thus, the VZV micrograph agrees with the data from Wild about "Virions are within ER cisternae." Data not shown by Wild lab. Harson and Grose have shown that VZV capsids without a thin envelope can be found in the cytoplasm.

Response: We have shown capsids in the cytoplasm in this manuscript (Figs.4B and 9B) and plotted the total number of capsids in the cytoplasm in Fig. 6 . We also showed capsids in many articles published earlier, e.g. Wild et al. 2005 (impairment of nuclear pores) or Leuzinger et al.2005 (The dual pathway). In these articles the difference between budding at Golgi membranes and wrapping by Golgi membranes is clearly shown.

The capsids do not appear to be within any Golgi derived compartment. See Figure 6 panel $A$, (Harson \& Grose, 1995). This micrograph provides evidence against the Wild hypothesis that herpesviruses are always retained within compartments derived from the ER or Golgi. There is one micrograph in the Wild manuscript that appears to resemble the VZV micrograph. See Wild manuscript Figure 9B, which shows a BoHV capsid (without a thin envelope) in the cytoplasm adjacent to a Golgi (or ER/Golgi) membrane. This single BoHV micrograph would seem to invalidate the Wild hypothesis that BoHV always is transported within ER or Golgi compartments?

Response: As discussed above, we postulate 2 pathways: 1) Budding at nuclear membranes followed by intraluminal transportation, 2) Release via impairs nuclear envelope followed by budding into Golgi (and other) membranes, or by wrapping (see Leuzinger et al, 2005, Wild et.al. 2005 and 2009). In introduction, we inserted the pathway via vesicle formation. We have also observed some formation of vesicles late in infection.

Differences between viral particles in ER cisternae and viral particles in vesicles near the outer cell membrane. As noted above, data from the Grose lab agree with data from the Wild lab that viral particles are found in ER cisternae. But the Grose lab finds differences between particles in ER cisternae and particles in vesicles near the outer cell membrane. ER cistern are irregularly shaped. Particles within ER cisternae have a thin envelope without an obvious electron dense outer coat (presumably the viral glycoproteins). Vesicles containing viral particles near the outer cell membrane often are circular with a single outer membrane. See Figure 8 panel A in Harson \& Grose (1995), for a clear VZV example. The vesicle contains 4 particles, 2 of which are perfectly enveloped, with clearly defined capsid, tegument and envelope with electron-dense outer coat. These particles are slightly larger in diameter than the thin-enveloped particles seen in the irregular ER cisternae. The VZ virions in the circular vesicles are similar to the BoHV virions shown by Wild in his Figure 9 panels $D$ and $E$. In other words, there clearly are two types of enveloped particles: particles with thin-envelope and particles with a thicker electron-dense envelope.

Response: Using freezing and substitution techniques we did not find differences in the viral envelope of virions in the PNS and ER. The virus particles in Harson at al. differ most probably because of preservation quality (in panel $8 \mathrm{~A}$ much of the substances are lost) and of the section plane.

Virions are within Golgi cistern? Wild discusses viral particles with spikes and viral particles without obvious spikes. Spikes presumably represent mature glycoproteins. One possibility that 
Wild has not considered is that viral particles may be routed in different pathways. Some viral particles may enter the large Golgi-like cisternae. Other viral particles may be wrapped in individual vesicles. Why does there need to be a single pathway for all viral particles?

Response: As stated above, we propose two diverse pathways indicated in Fig, xx by 1 and 2. However, we do not agree with the postulation, that de-envelopment followed by reenvelopment is essential for production of infectious progeny virus because Us3 deletion mutants are fully effective although $98 \%$ of these virions accumulate in the PNS and adjacent ER.

Lack of data about endocytic or autophagy pathways. There are now HSV and VZV papers that provide evidence for involvement of the endocytic and/or autophagy pathways in viral egress. The Elliott lab has shown that both Rab5 and Rab11 are involved in the final envelopment process for HSV. Further, they did not find co-localization of capsids with the TGN marker TGN46. See Hollinshead et al. 2012. The C. Grose lab confirmed that a fraction of purified VZ virions were positive for the Rab11 protein, presumably because the purified virions retained remnants of a Rab11-positive vesicle. See VZV article by Buckingham et al, 2016. The C. Grose lab also found the LC3-II protein in the same purified virion fraction and hypothesized that the virions were housed in amphisome-like vesicles, which contain both Rab11 and LC3-II proteins in their membrane. The fact that a HSV lab and a VZV lab both found Rab11 in the virion greatly strengthens the observation. These data are presented because they suggested that the Wild lab cannot determine the origin of the vesicles containing either HSV or BoHV virions by using only TEM and SEM. The Wild lab will need to use either immuno-TEM or alternatively isolate the HSV and BoHV particles, then examine them for proteins such as Rab11 and LC3-II by immunoblotting.

Response: The intention of this manuscript is to discover a possible intraluminal transportation route from the PNS into Golgi cisternae. No more no less. By no means does it question the existence of an "endocytic" pathway. Therefore, there is no need to repeat experiments other groups have done as cited for HSV-1 in introduction (Albecka et al. 2016, Holinstead et al., 2012). We will describe in detail this pathway in another manuscript. Considering membrane recycling, it would be a great surprise if an "endocytic" pathway would not exist. However, I do not think that capsids bud at endosomes per se. Possibly, they rather bud at membrane compartments that contain recycled (endosomal) membrane components.

Figure 11. Schematic drawings. If the Elliott lab and the Grose lab are correct that purified HSV or VZV contain Rab11 protein, then schematic pathway \#1 in Figure 11 cannot be correct. Also, if the Elliott lab and the Grose lab are correct, then secondary envelopment must involve an intersection of the virus with a pathway outside of the ER/Golgi pathway. Strongly suggest that the Wild lab investigate whether any of the vacuoles that contain either HSV or BoHV are positive for the Rab11 protein. Electron microscopy alone is not sufficient.

Response: The endocytic pathway will be included in Fig. 11. For simplicity, we removed pathway 3 because we did not find correct proves it. Instead, we introduced Figure 2 of Farnsworth et al., 2007 showing transport of capsids across the ONM and ER membranes in the absence of the fusion proteins $\mathrm{gB} / \mathrm{gH}$ and accumulation of virions in the PNS-ER compartment. 
Figure 7. Virus titers. cell by endocytosis. The titers at 8hpi probably represent viral particles formed after some actual HSV glycoprotThe data about the different titers with and without BFA may need re-interpretation. The titer is much lower when BFA was added at 5hpi. Most of these particles would be capsids and capsids with thin-envelopes. A titer of $1000 \mathrm{PFU} / \mathrm{ml}$ seems reasonable for capsids, which could enter a ein biosynthesis. Some VZV glycoproteins undergo their biosynthesis within 2 hours. See article from Grose lab by Yao et al, 1993. Presumably HSV glycoproteins are synthesized at the same rate. Therefore, addition of BFA at 8hpi would not prevent formation of substantial amounts of HSV glycoproteins, which would allow envelopment of viral particles, even by $8 \mathrm{hpi}$. In other words, I do not think that the BFA experiments add much weight to the arguments about which pathway HSV takes

Response: Glycoprotein of HSV-1start to be synthesised prior to $4 \mathrm{hpi}$ and are localized at the Golgi complex (unpublished data) which is in agreement with the biosynthesis of glycoproteins in VZV. In the work of de Oliviera et al., 2008, $\mathrm{gH}$ was found in the cytoplasm and at the nuclear periphery at $4 \mathrm{hpi}$. The proteins at nuclear membranes are used for envelopment after disintegration of the Golgi complex. The only way capsids can be enveloped after disintegration of the Golgi complex is by budding at nuclear and ER membranes. An important question is: where the capsids get their envelope after fragmentation of the Golgi complex in HSV-1 infection (Campadelli-Fiume et al., 1993)?

Bovine herpesvirus data. I do find inclusion of the BoHV micrographs to be informative. The BoHV data appear to resemble the VZV data more closely than the HSV data. Remember that BoHV is a member of the varicellovirus subfamily.

Response: The images of BoHV nicely show connectivity between PNS and Golgi via RER as well as the juxtanuclear position of the Golgi complex. Therefore, it is an important image to understand the relation between Golgi, ER, and PNS. ER-to Golgi transitions have been shown in many cells and are not induced by herpes viruses (see also comments of Gareth Griffiths).

Schematic pathway for VZV trafficking. Please take the time to look over the VZV pathway illustrated in Figure 8, in article by Buckingham et al, 2016. It resembles pathway \#3 by the Wild group.

Response: Pathway 3 was omitted in Fig. 11 because it is not our idea, and because the process at the ONM is not fusion (de-envelopment) as shown using a mutant lacking the fusion proteins $\mathrm{gB} / \mathrm{gH}$ that results in accumulation of virions in the PNS (see Fig.12). By the way, to distinguish between budding and fusion is as easy as to distinguish between the right and left shoe.

Competing Interests: No competing interests were disclosed. 
The benefits of publishing with F1000Research:

- Your article is published within days, with no editorial bias

- You can publish traditional articles, null/negative results, case reports, data notes and more

- The peer review process is transparent and collaborative

- Your article is indexed in PubMed after passing peer review

- Dedicated customer support at every stage

For pre-submission enquiries, contact research@f1000.com 